\title{
Historiografía de las Cruzadas
}

\author{
José Manuel Rodríguez García
}

\begin{abstract}
RESUMEN ABSTRACT
El presente trabajo historiográfico nació en el análisis de las obras interesantes para el estudio de las cruzadas en el siglo XIII (centrándonos en el ámbito del reino CastellanoLeonés), y abarcando desde la concepción de lo que llamamos «cruzadas» hasta su posterior evolución a lo largo del tiempo. Teniendo en cuenta que existió una historiografía de las cruzadas ya planteada por los mismos contemporáneos a los hechos, este estudio constituye un estado de la cuestión, viendo su origen y evolución, asi como la aportación de las diferentes escuelas históricas. Dedicamos un importante capítulo a la temática reconquista/cruzada en las obras escritas en España y sobre el

This article is an update of nine hundred years of crusading historiography. However, we will focus in the relationship between Europe and Castile and the works produced in the second half of the twentieth century. This essay was born during the study of the situation of the crusade in the $13^{\text {th }}$ century Castile. The relationship between Spain and Europe both from a historical point of view (importance of the iberian front in the origin of the crusades), and from a historiographical one (work written in and about Spain) is an important subject all along the paper. We study how the crusade has been understood in different ways and in different times... and how the study of the crusades is still a very alive and kicking topic.
\end{abstract} escenario peninsular, sin descuidar la aportación de la historiografía musulmana.

\section{INTRODUCCIÓN}

La presente publicación trata de rellenar un hueco importante y significativo en la historiografía peninsular, como es el de la relación entre lo que sucedía en la Península lbérica durante la edad media y lo que pasaba en el resto de Europa en torno al fenómeno de las cruzadas; 
con la esperanza de que sirva de base para futuras investigaciones al respecto.

Durante los últimos 10 años se ha trabajado mucho y bien en todo el mundo; 1995 fue especialmente un buen año para el estudio de las cruzadas que creo puede marcar un despertar en el estudio de este campo dentro de nuestras fronteras. Aprovechando el $9 .^{\circ}$ centenario de la proclamación de la 1. ${ }^{a}$ cruzada en Clermont, se desarrollaron diversos congresos y se publicaron varias obras en el extranjero, como es natural, e incluso en suelo Peninsular. He ahí las últimas aportaciones celebradas en los congresos celebrados en Clermont-Ferrand y Leeds en $1995^{1}$, la edición de la última obra sobre las cruzadas de Cambridge ${ }^{2} \mathrm{y}$, a nivel nacional, el congreso celebrado en Madrid (1995) ${ }^{3}$, la lectura de una tesis doctoral en Marzo de $1996^{4}$, e incluso la celebración de un curso de verano ${ }^{5}$. Esperemos que toda esa actividad no se quede en algo circunstancial. Nuestro propósito con el presente trabajo de investigación, y la tesis sobre la que también estoy trabajando, es establecer una de las bases para una nueva línea o campo de investigación dentro de la, hasta ahora, muy tradicional historiografía castellana ${ }^{6}$.

\section{Historiografía}

La Historiografía de las cruzadas es tan extensa y antigua como los propios hechos, ya que sus contemporáneos se encargaron de plasmar por escrito los acontecimientos, críticas y defensas, proyectos e incluso Historias.

1 Autour de la première croisade. M. Balard, ed. París, 1996; IX ̀̀me Centenaire du Concile de clermont. Le Concile de Clermont de 1095, et l'Appel á la Croisade, Roma, 1997; From Clermont to Jerusalem, 1095-1500. A. Murray, ed. Brepols, 1998.

2 The Oxford Illustrated History of the Crusades, Jonathan Riley-Smith, ed. Oxford, 1995

3 La primera cruzada novecientos años después. L. García-Guijarro, ed. Castellón, 1997. Durante las mismas se aprovechó para presentar el libro García-GuiJarRo Ramos, L., Papado, Cruzadas y Órdenes Militares, sigios XII-XIII, Madrid, 1995. Estas Jornadas han tenido una segunda continuación en las // Jornadas Internacionales sobre la / Cruzada, Huesca, en Septiembre de 1999.

4 Benito Rodríguez, J.A., «La Bula de cruzada de Indias», Dir. por Dr. D. Lucio Mijares Pérez, Universidad de Valladolid, 1996.

5 "Las Cruzadas». Curso de verano de la Universidad Complutense de Madrid, Junio, 1996. Dir. por José Luis Suárez y Carlos de Ayala Martínez.

6 El último trabajo que trata de las cruzadas en Castilla es EchevarRia Arsuaga, A., The Fortress of Faith. Perceptions of Muslim in $15^{\text {th }}$ century Spain. Brill, 1999. 
En éste trabajo veremos como esa diversa y múltiple historiografía se extiende a lo largo de todo el «periodo clásico de las cruzadas» (s. XI-XIII), y mucho más allá, en los siglos XV y XVI con aún importantes «hechos cruzados en marcha»; pasando por el siglo XVII, y a través de los ojos del siglo de la llustración, siglo xVIII, que básicamente veía en ellas una expresión colectiva de la estupidez y fanatismo occidental de una época bárbara. Atenderemos al despertar de la moderna historiografía cruzada en el siglo XIX, de manos de románticos y progresistas, a los que se les añadirán ideas imperialistas y la escuela positivista; para llegar a la historiografía y bibliografía actual, desde los años 20 de nuestro siglo y hasta hoy en día.

Por razones metodológicas y para favorecer la explicación vamos a dividir este apartado en 2 puntos. El primero tratará de la historiografía de la temática cruzada, en general. El segundo se centrará en el caso peninsular. Dejaremos para el siguiente capítulo una discusión más profunda sobre dos términos ejes de nuestro estudio: cruzada y reconquista.

\subsection{El desarrollo de la temática cruzada}

Algunos autores han afirmado que el primer historiador de las cruzadas fue Guillermo de Tiro, el cual escribió su famosa crónica entre 1169 y $1183^{7}$, donde se recogían todos los sucesos acaecidos en Tierra Santa desde el 1086 hasta el 1184. Si bien es cierto que fue el arzobispo Guillermo quien primero utilizó fuentes musulmanas para la construcción de su historia, no es menos cierto que todas las cruzadas o principales expediciones, desde la primera en 1096, tuvieron sus propios relatores.

En efecto, ya desde la primera campaña a Tierra Santa, la producción escrita y oral que se va a generar sobre ellas va a aportar dos influencias fundamentales a la historia de la literatura de la Edad Media ${ }^{8}$. Por una

ATIYA, A. S., Crusade Historiography and Bibliography, Oxford, 1962. Guillermo, criado en Tierra Santa, y educado en Francia y Roma, fue nombrado arzobispo de Tiro en 1160. Desde 1170 al 1174 fue también Canciller del Reino de Jerusalén, lo que le dio acceso a abundante documentación guardada en los archivos; así como a las obras de sus antecesores Fulcher de Chartres, Albert de Aachen, Raymond de Aguilers y Walter el Canciller, de igual modo que a algunas versones de la «Gesta Francorum». Su obra la tituló: «Historia rerum in partibus transmarinis gestarum a tempore successorum Mahumeth usque ad annum Domini MCLXXXIV" (en Recueil des Historiens des Croisades, Historiens Occidentaux, 5 vols., París, 1844-95).

8 Por ejemplo tenemos la Gesta de los Francos, o Gesta Francorum et aliorum Hierosomilitanorum, crónica anónima de la primera cruzada. Escrita en los primeros años del siglo XII y que muy probablemente se deba a un cabaliero de rango medio que participó en la misma (La Geste des Francs, París, 1992). Ya pasando al siglo Xlil tenemos las crónicas de 
parte, las narraciones de las cruzadas van a ser las primeras obras literarias que van a escapar al control de la Iglesia, y van a ser escritas bien por nobles o sus acompañantes en las cruzadas, bien por clérigos a su servicio o por cronistas locales. Todo ello, al mismo tiempo, va a generar una literatura en torno al héroe cruzado que va a dar origen a una estrecha relación con el tema fundamental de la literatura caballeresca medieval ${ }^{9}$, especialmente en Francia e Inglaterra, así como a una influencia en el propio ideal de la caballería ${ }^{10}$.

Por supuesto, los géneros que podemos incluir dentro de la historiografía cruzada de la época, ni se van a limitar al género narrativo/cronístico ni van a acabarse en 1291 con la caída de Acre. Dichos géneros, que podemos hallar tanto en la Cristianitas Europa como en los estados latinos de Oriente, van del ya mencionado narrativo/cronístico, como las diversas continuaciones de la obra de Guillermo de Tiro en Oriente y las diferentes crónicas de las campañas cruzadas de Occidente ${ }^{11}$, pasando por el género poético/trovadoresco ${ }^{12}$, el pura-

Enrique de Livonia para las cruzadas en el Báltico (The Chronicle of Henry of Livonia, Brundage, J.A., Madison, 1961; y The Chronicle of Novgorod, 1016-1471, Michell, R. y Forbes, N., Cambridge, 1914), Geoffrey de Villehardouin para la IV Cruzada o Jean de Joinville para la VII cruzada de San Luis, entre otras (Chronicles of the Crusades, Shaw, M. R., ed, Londres, 1963).

9 Como canciones de gesta como la de Ambroise, La Cruzada de Ricardo Corazón de León (Ricardo Corazón de León, Brossard-Dandré, M. y Besson, G., ed, Madrid, 1991). Especial influencia en la leyenda del grial y en la literatura de peregrinaje: CHRETIEN DE TROYES, Arthurian Romances; WOLFRAM VON ESCHENBACH, Parcival; Sir THOMAs MalORY, Le morte d'arthur, The travels of Sir John Mandeville; MITCHELL, R. J., The Spring voyage. The Jerusalem pilgrimage in 1458.; Geoffrey ChaUCER, The knight's Tale. Para estudios sobre todo ello: LoomIS, R.S., Arthurian tradjtion and Chretien de Troyes; LOOMIS, R.S. The Grail: from Celtic Myth to christian symbol; OWEN, D.D.R., The evolution of the Grail Legend; KNIGHT,S, Arthurian literature and Society, GRABOIS, A, "Christian pilgrims in the 13th century and the Latin Kingdom of Jerusalem: Burchard of Mount Sion", Outremer, 285-96, Londres, 1982; BRUNDAGE,J.A., "Cruce signari», Traditio,22 (1966): 289310; HYDE,J.K., "Navigation of the Eastern Mediterranean in 14th and 15th centuries according to pilgrim's books", Papers in Italian Archaelogy I, 521-540; KEEN, M., "Chaucer's Knight, the English Aristocracy and the Crusade", English Court Culture in the Middle Ages, 45-61.

10 AtiYa, A.S., The Crusade in the Latter Middle Ages, Londres, 1938; KeEn, M., Chivalry, New Haven, 1984; Barber, R., The Knight and Chivalry, Londres, 1970; Flory, J. Croisade et chevalerie. Bruselas, 1990.

11 Ver nota 7 supra, y continuaciones francas de la obra de GUILLERMO DE TIRO, primero hasta 1229, y luego de 1229 a 1261. Por supuesto la historiografía en tierras de Oriente acabaría en 1291, no así en occidente. Recueil des Historiens des Croisades. Historiens occidentaux. Tomo II. París, 1844-95.

12 Les Chansons des croisades, Bedier, J., ed. París, 1909. Jonin, A «Ambiente de Cruzada en los cantares de gesta", Epopeya e Historia, Cirlot, V. y Aiyot, ed, Barcelona, 1985. Un apreciable número de trovadores también abogaban por la extensión del término cruzado a otras campañas diferentes a las de Tierra Santa. HölzLE, P., «Kreuzzug und kreuzzugsdichtang. Das problem ihrer definition», Festgchrift für Kurt Herbert Holbach zunzo Geburstag, 55-77, Goppinger, 1972. Cit. por TrotTer, D.A., Medieval French Literature and the Crusades, Ginebra, 1988. También, Kates, J.A., Tasso and Milton: The problem of Christian epic, Londres, 1983. 
mente novelesco ${ }^{13}$ y llegando a auténticos ensayos sobre la necesidad o no de cruzada - su sentido, críticas y apoyos-; antes y después de $1291^{14}$; además de los usos literarios propiamente de la iglesia como sermones y predicaciones ${ }^{15}$.

Como se ha visto, las cruzadas, durante lo que se ha venido a llamar como la era tradicional (1095-1291), y durante toda la Edad Media generaron una abundante bibliografía de diferente índole, sin descartar en importancia el histórico. Sin embargo, como cualquier tema, también se usó el motivo de las cruzadas, por los propios contemporáneos, para justificar grandezas, retocar la historia y re-escribir el material histórico de una forma más o menos consciente ${ }^{16}$.

La historiografía de las cruzadas va a dar un salto cualitativo y cuantitativo hasta la aparición, en la primera mitad del siglo XIX, de dos obras

13 Tenemos diversos ejemplos de novelas de caballería inspiradas en las cruzadas o derivadas de ella. Un magnífico ejemplo lo constituye La Gran Conquista de Ultramar, obra francesa y traducida a los principales idiomas europeo, de donde derivan otras novelas caballerescas como el «Caballero del Zifar» y el «Caballero del Cisne» (Ambas en la edición de Echenique, M.T. Barcelona, 1989).

14 Para planes internacionales justo antes y después de 1291 ver: FIDENZIO DE PADUA, Liber Recuperationis Terre Sanctae, Golubovich ed. en Biblioteca Bio-bibliográfica della Terra Sancta e dell'Oriente Francescano, vol.II, Quarachi, 1913; PIERRE Dubols, The recovery of the Holy Land, Brandt, W.l., ed., Nueva York, 1956; Marino Sanudo, Liber Secretorum Fidelium Crucis, Bogars ed, en Gesta Dei per Francos, Hanover, 1611; FeliPE de MezIeres, Le songe du vieil pelerin, Coopland, G. W, ed; o las obras de Ramo LLull Blanquerna,(A. Soler ed. Barcelona, 1995) y el Libellus de Fine (Palma de Mallorca, 1986). Como principales estudios al respecto: SiBERRY, E., Criticism of Crusading, 1095-1274, Oxford, 1985, Ibid, "Criticism of crusading in 14th century England», Crusade and Settlemente, 127-34, Edbury, P.W. ed, Cardiff, 1985; THRooP, P.A., Criticism of the Crusades: a study on public opinion and crusade propaganda, Filadelfia, 1975; TYERMAN, C.J., "The Holy Land and the Crusades of the 13th and 14th centuries», Crusade and settlement, 105-112, Edbury, P.W., ed., Cardi, 1985; LEOPOLD, A. How to recover the Holy Land. Aldershot, 2000.

15 Ejemplos maestros de predicación para el siglo xill son los casos de Humberto de Roma y Jaques de Vitry (M. 1240), y Etudes de Châteauroux (Cardinal PITRA, Analecta Novisima Spicilegii Solesmensis, V. II, París, 1888, Frenken, G., Die exempla des Jacob von Vitry, Berlín, 1914). MCDONELL, E.W., The Beguine and Beghards in Medieval Culture, Oxford, 1954. Otros estudios: MoRRIS,C., "Propaganda for war and the dissemination of crusading ideal in the 12th century", Studies in Church History, 20 (1983): 79-101; MAIER, C.T., Preaching the Crusades: Mendicant Friars and the Cross in the thirteenth century, Cambridge, 1994; COLE, P.J., The preaching of the crusades to the Holy Land. Cambridge, 1991; MAIER Ch.T. Crusade propaganda and ideology: model sermons for the preaching of the cross. Cambridge: 2000.

16 TrotTER, D.A., Medieval french Literature and the Crusades, 1100-1300, Ginebra, 1988 (Más en concreto se refiere a Enrique II). Especialmente interesante para nosotros es el caso de Luis Marmol de carvajal: Descripción General de África, Granada, 1573. Obra escrita durante el periodo de formación de la Liga y que hace un repaso a toda la historia de las cruzadas, incluyendo a España, hasta su momento. Su fin evidente es animar a la guerra santa contra el turco a través del norte de África, poniéndola en estrecha relación con esas historias del pasado. Un mejor camino para acabar con el infiel que el ataque directo a Tierra Santa. 
que van a convertirse en clásicas y que se van a escribir en un momento en que la corriente Romántica barre toda Europa ${ }^{17}$ y hace atrayente los estudios de lugares exóticos, como oriente, y temas románticos como el de la marcha de los caballeros en una empresa a lejanas tierras. Éstas serán las obras de Michaud en Francia y Wilken en Alemania ${ }^{18}$. En medio queda unos escasos y hostiles trabajos, principalmente desde fines del siglo XVH a principios del siglo XIX -y especialmente con la llustración-, que van a considerar la Edad Media en general y las cruzadas en particular como un periodo de obscuridad y barbarismo ${ }^{19}$. De hecho, según Atiya, lo único realmente positivo durante ese lapso de tiempo intermedio fue la publicación de diferentes fuentes, incluidas algunas árabes, para el estudio del mundo cruzado ${ }^{20}$.

Michaud $Y$ Wilken van a volver a hacer uso de las fuentes árabes a las que tienen acceso, aunque el alemán las usara en mayor medida y de forma más positivista, alejándose algo del planteamiento romántico y moralizador de Michaud ${ }^{21}$. No cabe duda de que ellos impulsaron el estudio

17 Ejemplos peninsulares, aunque indirectos: Belleza de la historia de las cruzadas y de las diferentes órdenes religiosas y militares que de ellas han nacido desde su origen hasta su extinción. Por iv.G.; trad. al español por Francisco Pérez de Anaya. Madrid: 1833; Relaçao da derrota naval, façanhas e sucessos das cruzadas que partirao do Escalda para Terra Santa no anno de 1189. Trad. del latin y anot. por J. Baptista da Silva Lopes, Lisboa: 1844.

18 Michaud, J.F, Histoire des croisades, 3 vols, París, 1813-40. WiLKEN, E, Geschichte der kreuzzüge nach morgenländachen und abenländischen Berichten, 7vols. en 8, Leipzig, 1807-1832.

19 Fuller,T.H., Histoire of the Holy warre, 3. a ed, Cambridge, 1647; GuIGNes, J. de, Histoire des Huns, París, 1756-58; MAILlY, J.B, L'Espirit des Croisades, 4 vols., Dijon, 1780; HELLER, F.W., Geschichte der Kreuzzüge nach dem heiligen Lande, 3 vols., Manheim, 1816; y HAKEN, J.C.L., Gemälde der Kreuzzüge nach Palestina zur Befreung des heiligen Grabes, 4 vols., Frankfurt, 1808-20, cit. en ATIYA, A., Historiography..., pp. 18-19. O en palabras de Gibbon (2/2 s. XVII)" (las cruzadas) ...fueron una expresión del fanatismo religioso e intransigencia del hombre medieval en esa época obscura, ...fruto de la lujuria material y ansia de libertad» (GıBвON, E., Decline and fall of the Roman Empire, Londres, 1787; cit. en The Crusades Motives and Achievements, Brundage, J., ed., Boston, 1969).

20 En 1611, en Hanover, Bongars publicó su Gesta Dei per Francos, en dos volúmenes dedicados a fuentes occidentales. Desde principios del siglo XVIII los benedictinos empezaron a compilar una serie de fuentes para la historia del Oriente Latino, muchos de ellos plasmados hacia 1740 en la Histoire Littéraire de la France, lo que motivó que se le encargara, en 1770, a Dom Bertherau una edición de las fuentes para las cruzadas, incluidas algunas árabes. Su trabajo inacabado fue continuado, en cierta medida, por el propio MicHAUD en su Bibliothéque des croisades, París, 1829. A lo largo del siglo XIx habría que añadir la labor de la Academia de Inscripciones y Bellas-artes de Francia (Recueil des Historiens des Coisades, París, 1841-1906), y la de la Sociedad del Oriente Latino con sus diferentes series en su Monumental Collections. Atiya, Historiography..., pp. 19-21.

21 MichaUd, J.Fr., Histoire des Croisades, 2. a ed. Madrid, 1970. La primera edición española data de 1886. Michaud tampoco es ajeno a las corrientes históricas contemporáneas que afectan a cualquier historiador, y en su obra se puede apreciar cierta intencionalidad política defensora de la creación de un nuevo imperio europeo... 
de la Edad Media y las cruzadas. En cualquier caso, a partir de ahora, ya va a quedar clara la postura de dos escuelas historiográficas respecto a las cruzadas: La francesa y la alemana. A ellas se uniría, a finales de siglo, una creciente obra inglesa, mientras que no es hasta después de la I guerra mundial cuando se considera que toma cuerpo la escuela Americana de historiadores de las cruzadas, alrededor de D. Munro y A.C Krey ${ }^{22}$, con sus focos de Winsconsin y Princeston ${ }^{23}$.

Durante una primera época que podríamos delimitar hasta inicios de la II guerra mundial, la historiografía de las cruzadas se va a destacar por seguir una corriente necesariamente positivista, buscando la relación exacta de los hechos y profundizando en el estudio de las fuentes, y discutiendo sin parar, como se sigue haciendo aún, sobre los orígenes, motivos y objetivos de la primera cruzada. De ésta época son los trabajos clásico de René Grousset, y F. Chalandon en Francia ${ }^{24}$; Hagenmeyer y $\mathrm{C}$. Erdman ${ }^{25}$ - con un trabajo innovador en muchos aspectos y aún de obligada lectura-, en Alemania; o Munro y Krey en los Estados Unidos ${ }^{26 .}$

Podríamos definir otra segunda etapa desde inicios de los años cuarenta hasta mediados de los sesenta, tiempo en que van a terminar sus principales trabajos investigadores de la talla de Runciman -con un tipo de trabajo altamente narrativo y positivista-, Atiya, Toinbee, o Delaruelle ${ }^{27}$. En ésta época van a continuar importantes trabajos sobre historia política, como los de Runciman, acompañados por una creciente preocupación por la «ideología de la cruzada» como en el trabajo de Delaruelle ${ }^{28}$, su evolución tanto en términos políticos como legales ${ }^{29}$, etc.

22 KREY, A.C., The Kingdom of Jerusalem, Princeton, 1935 (Utilizando materiales del difunto Munro).

${ }^{23}$ The Crusades, motives and achievements, Brundage, J., ed., Boston, 1969. A fines del XIX ya se había publicado en USA una obra especie de compilación del conocimiento de las cruzadas hasta la época: ARChner, T.A. y Kinsford, C.L., The Crusades, Nueva York, 1894.

24 Grousset,R, Histoire des Croisades et du Royaume Franc de Jerusalem, 3 vols., París, 1934-36. Chalandon, F., Histoire de la premiére Croisade, París, 1925. Fliche, A. y Martin, E., Histoire de /'Eglise, París, 1935-41.

25 RöHRICHT, R, Die Kreuzzugsbriefe, Berlin, 1905. HAGENMEYER, H., Geschichte der ersten Kreuzzuges, Insbruck, 1901. ERDMAN, C., Die Entstehung des Kreuzzugsggedanken, Stutgart, 1935

26 KREY, A.C., «Urban's Crusade, Succes or Failure?", American Historical Review, LIII (1918):235-250. Munro, D.C, "The speech of Pope Urban II at Clermont", American Historical Review,XI (1906).

27 Runciman, S.R., A History of the Cruzades, Cambridge, 1954. ATiYA, A.S, The Crusades in the Latter Midlle Ages, Indiana, 1961. TOYNBEE, S. The Crusades. A militaire failure. Oxford, 1952

28 Delaruelle, E., «Essai sur la formation de lídée de Croisade», Bulletin de Litterature Ecllesiastique (1941, 1944, 1953, 1954): 24-45 \& 86-110, 13-46 \& 73-90, 226-239, 50-63; o ALP. handery, P. y Dupont, A., La Chrétienté et l'ldée de Croisade, 2 vol, París, 1954.

29 VILLEY, M., La Croisade: Essay sur la formation dúne théorie juridique. París, 1942. 
Al mismo tiempo se trabaja y se profundiza en nuevos temas como los aspectos económicos-comerciales ${ }^{30}$, la religiosidad popular ${ }^{31} \mathrm{u}$ otros temas que van a estudiarse de una forma mucho más científica como el desarrollo militar y tecnológico ${ }^{32}$, o los estudios orientales ${ }^{33}$. Para Atiya, que publicó su trabajo sobre historiografía cruzada en 1962, «la necesidad real en el campo de las cruzadas son las monografías por especialistas de biografías de dirigentes y hechos señalados, de flientes, de relaciones de viaje, de textos propagandísticos, de un castillo o un monumento, de evidencias numismáticas...» ${ }^{34}$. Ciertamente los campos por explorar no eran pocos, y aún así fueron aumentando.

Por otra parte y en consonancia con los trabajos de la escuela francesa comenzados por C. Cahen, en la década de los 30 , acerca de la creciente preocupación por la temática cruzada considerada desde el punto de vista del «enemigo», tenemos ya resultados considerables al respecto, como las propias obras de Cahen $(1940,1950,1968,1983)$, Daniel (1960), Sivan (1968) y Holt (1986), que junto con otros, aún hoy en día, siguen trabajando en el campo de las influencias mutuas a través de la acción de las actividades guerreras «santas» de ambas sociedades: cruzada y yihad ${ }^{35}$.

Desde finales de los cincuenta, y durante 20 años, los estudios de $\mathrm{J}$. Richard y J. Prawer sobre el este latino y sus instituciones darán nueva vida al debate historiográfico a la vez que lugar a otro nuevo campo de investigación referente a la constitución y gestación de los estados cruzados. Campo que a finales de los 70 será complementado por estudios más detallistas y regionales ${ }^{36}$, sobre los que aún se trabaja.

30 ATIYA, A.S., Crusade, commerce and culture, Indiana, 1962. LópeZ, R.S. y RAYMUnD, I.W. Medieval trade in the Mediterranean world, Nueva York, 1955

31 Porges, $W$., "The cleregy, the poor and the non-combatants on the first Crusade", Speculum, XXI (1946): 1-21.

32 Lot, F., L'Arte Militaiere et les Armées au Moyen Age, 2 vols, París, 1946. Small, R.C., Crusading Warfare, Cambridge, 1956.

33 CAHEN, C., La Syrie du Nord a l'epoque des croisades et le principaute franqué d'Antioche, París, 1949. Hodgson, M.G.S., The Order of Assasins, Cambridge, 1955. HILl, G.F., A History of Cyprus, Cambridge, 1940-48.

34 ATIYA, Historiography..., p. 23.

35 KEDAR, B.Z., «Croisade et Jihad vus par lénemi. Un étude des perceptions mutuelles des motivations», Autour.., 345-358; PARTNER, P., «Holy War, Crusade and Jihad: an attempt to define some problems", Autour ..., 333-344.

36 RiChARD, J., The Latin Kingdom of Jerusalem, Oxford, ed. rev.: 1979; Prawer,J., The Latin Kingdom of Jerusalem: European colonialism in the Middle Ages, Londres, 1972, o ibidem, Crusader Institutions, Oxford, 1980. 
A mediados de los sesenta nos encontramos con un trabajo de tipo clásico como el de Z. Oldenbourg ${ }^{37}$, junto con otro, que va a representar una gran convulsión dentro del mundo de los especialistas, como es la obra de Hans Mayer ${ }^{38}$, al tiempo que se va a realizar el primer intento de una magna obra que comprenda de forma general todo el mundo de las cruzadas ${ }^{39}$. Junto con el progresivo y continuo desarrollo de estudios de tipo político, y la sistematización de estudios sobre Órdenes Militares, legislación y recursos, asistimos a una primera gran ampliación de horizontes en la temática cruzada. También por esta época, el gran desarrollo metodológico experimentado por la arqueología así como el número de excavaciones, se va a mostrar como una muy útil herramienta de trabajo para la historia del poblamiento-colonización y asentamiento ${ }^{40}$, la historia del arte y fortificaciones ${ }^{41}$, comunicaciones y comercio ${ }^{42}$; fenómenos todos ellos tan ligados al mundo cruzado, tanto en Tierra Santa como en occidente.

También es ahora cuando se intentan aclarar conceptos de estudio, empezando por la propia definición de lo que se puede o debe entender por "cruzada». Se establecen claramente 3 posturas: aquellos - los «tradicionalistas» 0 "singularistas»- que sólo admiten como cruzadas las que tuvieron como destino Tierra Santa, llegando al punto de que para algunos sólo hubo una verdadera cruzada, la primera; otros —los «pluralistas»-,

37 OldendBourg, Z., Les Croisades, París, 1968. Ciertamente algo novelado.

38 MaYer, H.E., Der Kreuzzugs, Stuttgart, 1964.

39 SETton, K.M. (ed. jefe), A history of the Crusades, $2 .^{2}$ ed., 6 vol. hasta la fecha, Princeton, 1969-1989.

40 Prawer, J., "The settlement of the latins in Jerusalem», Speculum, 27 (1952): 490-503, Prawer, J., The world of the Crusaders, Londres, 1972; JacobY, D., "Crusader Acre in the Thirteenth century: Urban Layout and topography", Studi Medievali, 30 (1987): 9-34; PringLE, D., The churchs of the Crusader Kingdom of Jerusalem and Cyprus, Cambridge, 1993. BoAs, A.J., "A newly discovered Twelfth century Frankish Village», Autour..., 583-594, GERTwaGEN, R., "The port of Acre during the Crusader period: the Urbanistic Layout and problems of Maintenance", Autour..., 553-582.

41 Ya previamente: Deschamps, P., Les Chăteaux des croisés en Terra Sainte, París, 1934-39. BOASE, T.S.R., "Military Architecture in the Crusaders Satates in Palestina and Syria", A History of the Crusades, Setton, K.M. ed., vol. IV, Madision, 1977. LawawnCE, T.E., Crusader Castles, Londres, 1986. Pringle, R.D., "Reconstructing the Castle of Safad", Palestine Exploration Quaterly, 117 (1985): 15-43. Kennedy, H., Crusader Castles, Cambridge, 1994. Ellenblum, R., "Three generations of Frankish castle-building in the Latin Kingdom of Jerusalem", Autour.., 517552.

42 PryoR, J.H., "Transportation of horsesby sea during the Era of the Crusades», The Mariner's Mirror, 68 (1984): 100-125. JACOBY, D., Studies on the Crusaders States and on Venetian expansion, Northampton, 1989. MoLLAT, M., «Problemes navals de l'histoire des croisades», Cahiers de civilisation Medievale, X (1967): 345-349. ABULAFIA, D., Commerce and Conquest in the Mediterranean, 1000-1500, Aldershot, 1993. 
entre los que nos encontramos -y siempre estudiando cada caso- afirman que si los propios contemporáneos consideraban como cruzadas a otras campañas con objetivos diferentes a Tierra Santa no es ahora momento para delimitar ese sentido de cruzada y, por lo tanto, son perfectamente válidas en ese sentido campañas de la Reconquista, expansión en el Báltico u otras, decretadas por los pontífices, contra heréticos y enemigos de la Iglesia. Otros, finalmente, adoptan una posición intermedia ${ }^{43}$. Ello conllevará, de manera lógica, una expansión historiográfica sobre las «no-cruzadas" o «desviaciones de las cruzadas» anteriormente mencionadas ${ }^{44}$. Debate, por otra parte, que aún continúa abierto, y del que trataremos en el próximo capítulo.

En los años ochenta del presente siglo asistimos a una nueva ampliación de la temática cruzada. Junto con los clásicos temas de concepción, origen, desarrollo, estudio legal, y la continua evolución en estudios arqueológicos y sobre Órdenes Militares; surgen otros nuevos como el papel de la mujer ${ }^{45}$, la religiosidad popular, historia social, imagen y concepción del enemigo, y otro, especialmente amplio, como es el del «home front» (retaguardia), es decir, cuál fue el impacto de las cruzadas, y las necesidades que conllevaban, en los propios solares de origen de los cruzados ${ }^{46}$. Ello engloba temas tan dispares como son reclutamiento, impacto de las cruzadas en el desarrollo económico/fiscal de los países, uso político de las cruzadas a nivel interno y diplomático, influencias literarias en occidente, etc.

43 Por ejemplo, últimamente, Tyerman destaca ante todo el elemento «popular» como definidor de la cruzada, llegando a decir que durante el siglo xil no existió ninguna verdadera cruzada, salvo quizás la de Ricardo corazón de León, ya que todas las campañas tanto en Tierra Santa como en la Península lbérica carecian de ese motor popular fundamental. TyERMAN, Ch., «12 century Crusades", English Historical Review, 110 (1995): 423-437.

${ }_{44}$ Para la época de finales del siglo XIX hasta finales de los 70, las mejores obras donde consultar bibliografía son las de Runciman, Mayer, Setton y Oldenbourg, ya mencionadas.

45 BRundage, J.A., «The Crusader's wife revisited», Studia Gratiana, 14 (1969): 241-251. BRundaGe, J.A., "Prostitution, miscegenation and sexual purity in the first crusade", Crusade and Settlement, 45-67, Edbury, W.P. ed., Cardiff, 1985. HAMLTON, B., «Women in the Crusader states", Medieval Women, 143-74; Pernoud, R. Le femme di temps des croisades. París, 1990; RoGERS, R., «Women and siege warfare the the Age of the Crusades», 28th International Congress on Medieval Studies, Kalamazoo, mayo, 1993. FrIEDMANN, Y., «Women in captivity and their ransom during the Crusader period", Cultural Convergences in the Crusader Period, Goodich, M., Meche, S. \& Schein, S. eds., 75-117, Nueva York, 1995. HemptinNe, T. de, «Les épouses des Croisé at pèlerins flamands aux 11 et $12 \mathrm{e}$ siècles (leur röle dans le Comté et en Orient», Autour..., 83-98.

46 Ver: Jordan, W.C., Louis $I X$ and the Challenge of the Crusade, Princeton, 1979; LLOYD, S., English Society and the Crusade, 1216-1307, Oxford, 1988; TyERMAN, C., England and the Crusades 1095-1588, Londres, 1988. 
Desde otro punto de vista, se pueden localizar la mayoría de los investigadores en cinco áreas, sin perjuicio de otras zonas (como Italia ${ }^{47}$ ): Estados Unidos (principalmente alrededor de las universidades de Princeton, Yale, Wisconsin, UCLA y Kalamazoo), Francia, Reino Unido (especialmente alrededor de Oxford, Cambridge, Londres y Durham), Alemania y como importante nuevo foco desde la década de los setenta del siglo $\mathrm{XX}$, Israel.

La evolución historiográfica no se ha detenido en estos últimos diez años, siendo especialmente rica en calidad y cantidad (incluyendo un buen número de trabajos recopilatorios de varios maestros). Además, tenemos nuevos temas como son la cuestión de liderazgo de las campañas, la cuestión de la predicación, las cruzadas o la guerra santa desde el punto de vista de los propios musulmanes ${ }^{48} \ldots$ al tiempo que se continúa y se hace hincapié en biografías, estudios locales de impacto, fuentes, arte ${ }^{49}$, arqueología, Órdenes Militares y un renacimiento de la historia militar ${ }^{50}$.

\subsubsection{La historiografía árabe de las cruzadas}

Hasta ahora hemos visto el desarrollo de lo que es la historiografía occidental cristiana. Pero al igual que la civilización Islámica tenía su propia concepción de guerra santa - la «yihad», como veremos más adelante-,

47 Con historiadores como Cognasso, F., La Genesi delle Crociate, Turín, 1934 (ampliado en Storia delle Crociate, Varese, 1967); FASOLI, G., La crociate, 1957; GABRIELI, F., Arab historians of the Crusades. Londres: 1984. (Trad. del italiano, Roma, 1980); O BeLLINI, .P., // gladio belico: i/ tema della guerra nella reflessione canonistica della etá clásica, Roma, 1989; y, sobre todo la prolífica obra de Cardini (desde su época de CARDinI, F., La Crociate: tra el mito e la storia, Roma, 1971).

${ }_{48}$ La Society for the Study of the Crusades and the Latin East publica anualmente un boletin donde se recogen gran parte de las aportaciones sobre este campo delas cruzadas.

49 FOLDA, J., The art of the Crusaders. Cambridge: 1995.

so MarShall, C., Warfare in the Latin East, 1191-1291, Cambridge, 1992; MARVIN, L.W., "The Non-Knightly soldier in the Crusades of the Twelfth century: his role and importance", 29th International Congress of Medieval Studies, Kalamazoo, 1994; BENNET, M., «The Crusaders's "Fighting March" revisted", War, Army and Society in Eastern Mediterranean, 7th16th centuries. Y. Lev, ed., Leiden, 1995; PRINGLE, A., «Town defence in the Crusader Kingdom of Jerusalem", The Medieval city under siege, Corfis, A. y Wolfe, M. ed., 55-87, Pensylvania, 1995; Bowlus, Ch.R., «Mounted archers on the eve of the First Crusade; their strategic and tantical weakneses", IV Colloque International, La prémiere Croisade et ses conséquences, SSCLE, 159-166, Clermont-Ferrand, 1996; FRIEDMAN, Y., «The Ransom of Captives in the Latin Kingdom of Jerusalem", IV Colloque International, La prémiere Croisade et ses conséquences, SSCLE, 177-192, Clermont-Ferrand, 1996. FRANCE, J., Western warfare in the ageof the Crusades. Londres: 1999; PringlE, D. Fortification and settlement in crusaders palestine. Aldershot, 2000. 


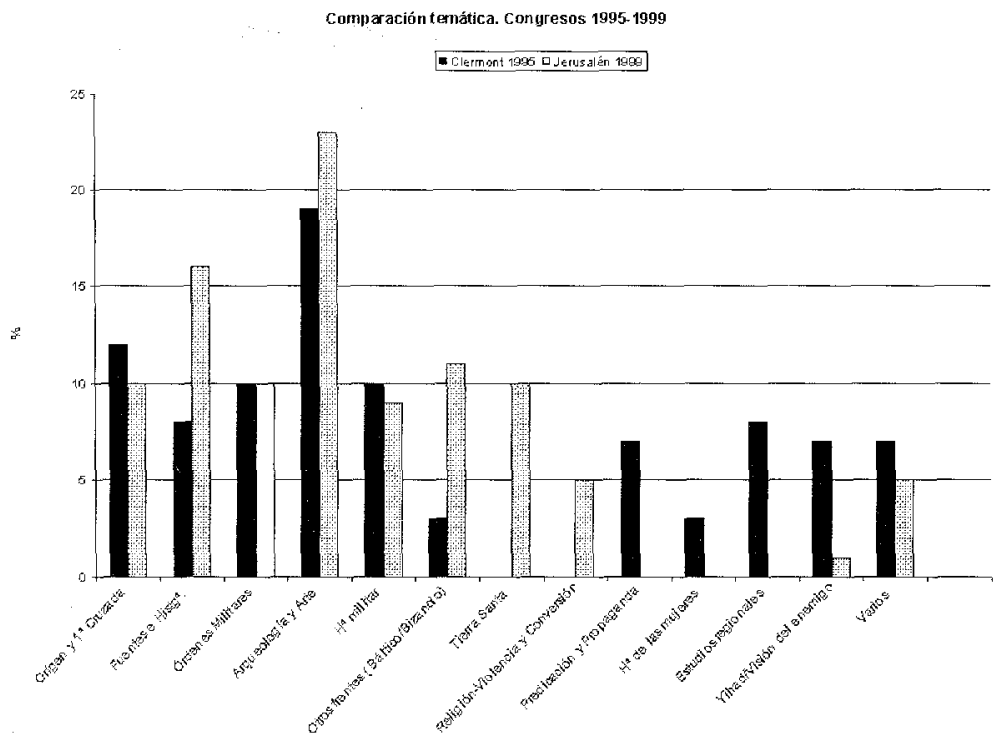

los musulmanes, objeto de esas cruzadas cristianas, tienen algo que decir. Nos interesaremos por la opinión que suscitó entre los escritores musulmanes de la época las campañas cruzadas realizadas contra ellos, ¿las veían como algo diferente? ¿diferenciaban los elementos que las integraban? ¿había una variación entre la visión que se tenía en oriente y occidente?

«El concepto de las cruzadas como un fenómeno histórico en sí mismo, con sus propias características, que podría ser tratado separadamente... es algo extraño a la historiografía musulmana... Los musulmanes nunca llegaron a considerar los ataques cristianos en el occidente como algo fundamentalmente diferente de otras guerras contra los infieles, tanto si fueran Francos, como bizantinos: en Siria,... en Al-Andalus... o en Sicilia...Incluso el famoso pasaje de Ibn al-Athir en que se compara la $1 .^{a}$ cruzada con las ofensivas cristianas en la reconquista hispana y con Sicilia ${ }^{51}$, aunque muestra la amplitud de la visión del historiador iraquí,

51 Ibn al-Athir (fines S. XIII) era más o menos heredero de las consideraciones del damasceno al-Sulami (1105) que veía las campañas cristianas dentro de un movimiento más amplio de confrontación de las dos religiones a lo largo de todo el Mediteráneo. En la crónica de Ibn al-Athir leemos: "La primera aparición del imperio de los Francos, el auge de su poder, su invasión de las tierras del Islam y la ocupación de algunas de ellas ocurrió en el año 478 (1085-1086), cuando 
nos prueba que él no percibe lo que diferenciaba a las cruzadas de las otras guerras entre cristianos y el Islam en la edad media» 52.

$\mathrm{Ni}$ siquiera se molestaron en dar nombres diferentes o específicos a los diferentes pueblos o naciones que dirigieron cruzadas contra ellos, llamándoles en general «francos» (Faran, Ifranj, Rum), al igual que a todos los habitantes del antiguo imperio carolingio ${ }^{53}$. En realidad no fue hasta la segunda mitad del siglo XIX, y por influencia francesa, cuando tenemos los primeros trabajos musulmanes, del este mediterráneo, dedicados específicamente a las cruzadas ${ }^{54}$.

Así, si alguien quiere buscar en fuentes árabes anteriores a la segunda mitad del pasado siglo estudios sobre las cruzadas, verá que sólo podrá encontrar referencias dispersas en diferentes obras histórico-cronísticas (empezando por Ibn al-Quitar, siglo XII), algunos poemas y las obras laudatorias biográficas y genealógicas. No hay ningún capítulo o estudio específico dedicado a ello. Gabrieli encuentra la explicación en una conciencia musulmana de superioridad frente a occidente que provoca el más absoluto desinterés hacia todo lo que venga de allí, aunque por supuesto reaccionaran ante ataques armados. Eso hace que los historiadores musulmanes no se molestaran en investigar las verdaderas causas de esos ataques y comportamientos cristianos, más allá de sus referencias más cercanas ${ }^{55}$.

Los dos primeros trabajos que se preocuparon de una manera importante y moderna de las cruzadas fueron las obras de Sayyid 'Ali al-Hariri

ellos tomaron la ciudad de Toledo y otras en la tierra de al-Andalus, como ya se ha contado. Entonces, en el año 484 (1091-92), atacaron la isla de Sicilia, y la conquistaron, como también ya he relatado antes. Después, forzaron su camino incluso a través de las costas del norte de África, donde tomaron unos pocos lugares, que, sin embargo, pudieron ser recobrados luego. Entonces conquistaron otros sitios, como ahora veréis. Cuando en el año 490 (1096-97) vinieron, invadieron la tierra de Siria», cit. InWIN, R., "Islam and the Crusades, 196-1699». The Oxford Illustrated History of the Crusades, dir. J. Riley-Smith, ed. Oxford, 1995, p. 226.

52 Gabriell, F., «The Arabic Historiography of the crusades», pp. 98-99, B. Lewis \& P.M. Holt, ed., Historians of the Middle East, Londres, 1962, pp. 98-107. Ver también de él: «La Cruciate vista dell' islam», Concetto, Storia, Miti e imagini del medio evo, V. Branca, ed. (Civilitá veneziana: aspetti e problemi, 7), pp. 183-198. Florence, 1973... y su recopilación, Storici árabe delle crociate, Turín, 1957 (París, 1977, Londres, 1984).

53 Ya veremos cómo el caso peninsular es algo distinto, ya que las fuentes suelen partir de la diferenciación entre "gallegos» (que serían los castellano-leoneses) y «francos» (aragoneses-catalanes y extranjeros en general). Al respecto: LA PIEDRA, E., Cómo llamaban los musuimanes a los cristianos. Alicante: 1997.

54 SiVAN, E., "Modern arab historiography of the crusades»Interpretations of Islam, cap. I, Princeton, 1987, pp. 3-43. Ver también su L'Islam et la Croisade, París, 1968.

55 Gabriell, F., «The Arabic Historiography of the crusades», B. Lewis \& P.M. Holt, ed., Historians of the Middle East, Londres, 1962, p. 101. 
-aún muy tradicional- y la del más moderno Yusuf al-Dibs, arzobispo maronita de Beirut ${ }^{56}$. De hecho, durante los primeros 30 años del presente siglo la producción historiográfica fue básicamente realizada por cristianos «Levantinos» 57 . Éstos fueron sustituidos por los musulmanes egipcios desde poco antes de la II guerra mundial, y, especialmente, después de ella. Es ahora cuando su historiografía está teñida por un fuerte carácter nacionalista y de liderazgo del egipcio sobre el resto de las naciones de su contorno. Para ello se hará especial referencia a figuras de su historia que las muestran como símbolos de libertad, independencia y liderazgo. De ahí la extensa producción sobre la figura de Saladino y su época, como cabeza de la yihad frente a los invasores exteriores. La labor historiográfica se aceleró a partir de 1952 —revolución egipcia-, aunque aún así no deja de ser discreta ${ }^{58}$.

Según Sivan, los elementos que influyeron en el nacimiento y florecimiento de esta historiografía árabe oriental de las cruzadas fueron: la influencia cultural del círculo francés en Siria y Líbano, el creciente contacto con la historiografía occidental de las cruzadas, el desarrollo general de los estudios históricos en el mundo árabe y el esfuerzo particular de una serie de pioneros, principalmente historiadores egipcios. A ello habría que unir un factor contextual como fue la conciencia, primero entre los círculos culturales y luego en los populares, de que las cruzadas fueron un suceso importante para la historia del pueblo árabe y que aún tienen importantes repercusiones en el mundo actual.De ahí no es de extrañar las posturas contemporáneas de considerar a los judíos, protegidos por los poderes occidentales, como los nuevos cruzados en Levante y la consiguiente respuesta de elementos árabes en forma de yihad, contra ellos.

Partiendo de la conciencia, por parte de los historiadores árabes, de que estas guerras fueron llevadas a cabo, por ambas partes, en nombre de la religión (cruzada Vs Yihad; por supuesto con razones más puras en el lado musulmán...), podemos distinguir varias escuelas de pensamiento en su historiografía. Hasta la segunda guerra mundial se veía el fenómeno

56 SAYYID 'ALI AL-HARIRI, The splendid history of the Crusading Wars, Cairo, 1899; Yusuf alDibs, Ta'rikh Suriya. 6 vols. Beirt, 1901, pp. 1-309, cit por SIVAN, E., «Modern arab historiography of the crusades" Interpretations of Islam, cap. I, Princeton, 1987, n. ${ }^{\text {os }} 6$ y 5 .

57 Usamos el adjetivo «levantino» al referirnos a los territorios y pobladores del mediterráneo oriental, que ocuparian las zonas de asentamiento de los reinos cruzados de Oriente.

58 Ver el artículo de QUSTI ZURAIQ, «ma sahama bihi al-mu`arrikum al-`arab...», al-Abhath, 12 (1959): 286-293. Cit. por SIVAN, E., «Modern arab historiography of the crusades» Interpretations of Islam, cap. I, , Princeton, 1987. n. os 8 y 9 . 
dentro de un proceso de enfrentamiento Islam-Cristiandad, de conquista árabe, respuesta cruzada occidental ${ }^{59}$, contra-expansión otomana y nueva/actual penetración occidental. Después de la guerra se vieron las cruzadas como la primera muestra de colonialismo europeo, reafirmada por la expansión europea de los siglos XIX y XX, y el contemporáneo asentamiento judío. Así se identificaría cruzada con Imperialismo; una teoría más secular que la anterior, pero no muy diferente a ella, pecando ambas de un claro partidismo ${ }^{60}$.

Una tercera teoría es la expuesta por Aziz Atiya ${ }^{61}$ en todas sus obras, y que ya a conseguido crear una cierta escuela, en la que incluimos a Hitti ${ }^{62}$. Él ve las cruzadas como un producto de la tradicional confrontación Este-Oeste, que mana desde la antigüedad y que llega hasta la actualidad. Algo que ya habíamos visto en la historiografía occidental, en obras como las de Grousset o Runciman. Al menos Atiya evita el partidismo de que sólo un lado -el cristiano- fuera el constante agresor, y se muestra mucho más interesado por la consulta de las fuentes primarias cristianas; intentando contextualizar todos los encuentros.

Al final, según Hilienbrand, se ha llegado a dos posturas. Una, que más que estudio científico histórico, usa la historia como base o excusa para sostener ideologías modernas, como la jihad. Otra, en la que los historiadores de lengua árabe citan a historiadores occidentales mientras que apenas, por otra parte, hacen crítica alguna de las fuentes islámicas consultadas, destacando el olvido de la importancia turca en el fenómeno de la contracruzada en el siglo XIII ${ }^{63}$.

Como se ha podido ver en todo este capítulo me he venido refiriendo a la historiografía árabe oriental. Ello lo he podido realizar gracias a la importante labor historiográfica de Gabrieli y Sivan, entre los ya citados ${ }^{64}$.

\footnotetext{
59 Para algunos autores árabes esa expansión general cristiana era la misma tanto en oriente como en el occidente del mediterráneo. Por ejemplo, IBN AL-ATHIR, Al-amil fil-Ta'rikh, vol. 10, Cairo, 1303, Hégira, p.94. Cit. Sivan, p. 8, n. ${ }^{\circ} 32$.

60 Por ejemplo: Sa id Ashur (History of te Crusades) (obra en árabe), Cairo, 1963. Cit. por SIVAN, E., "Modern arab historiography of the crusades", Interpretations of Islam, cap. I, Princeton, 1987, pp. 5-9 y n. ${ }^{\circ} 25$. En general de todas las obras árabes se encuentran referencias en los citados capítulos de Gabrieli y Sivan.

61 ATiYA, A., Crusade, commerce and Culture, Indiana, 1962; idem, The Crusade in the Later Middle Ages, Londres, 1938.

62 HITTI, P., KH, Islam and the West, Nueva York, 1962.

63 Hillendrand, C., The Crusades. islamic perspectives, Univ. Edimburgh, 1999, pp. 4-5 y 10-12.

64 A ello se debe añadir: FiovanI PIACENTINA, $V$., "Le crociate viste dell'Islam (parte I)". Nuova revista historica, LXXI (1987): 225-250; MICHEAU, F., «Croisades et croises vus poa les historiens àrabes chrétienes d'Egipte». Itinèraires d'Orient; hommages à Claude Cahen. Bures-sur-yvette, 1994, pp. 169-184.
} 
Sin embargo sería realmente interesante conocer esas mismas posturas y evolución historiográfica para la vertiente occidental musulmana del mediterráneo; es decir un trabajo basado en las obras y autores modernos de al-Andalus y el Maghreb. Desgraciadamente ese estudio, que nos afectaría mucho más directamente a nosotros ya que por fuerza debería tratar de la confrontación en la península ibérica, italia y norte de áfrica, está aún por hacer.

\subsection{La cruzada: Evolución de su definición Histórica e historiográfica ${ }^{65}$}

Hasta ahora hemos estado hablando más que nada de los distintos apartados temáticos que han ido apareciendo a lo largo de la evolución de la historiografía cruzada. Pero ¿qué es o fueron las cruzada para esa misma historiografía moderna, desde fines del XIX? ¿existe una opinión común u homogénea de qué es una cruzada? ¿ha habido evolución, o no...?

Por supuesto, no es misión de este trabajo realizar un estudio sobre el origen, significación y evolución de «la cruzada». Sin embargo, es inevitable realizar un repaso historiográfico de lo que se entiende por cruzada en el entorno científico-histórico actual para aclarar significados e implicaciones; teniendo en cuenta que ha habido diferentes interpretaciones a lo largo de la historia, reflejo también de la mentalidad de la época y sus autores. El estudio moderno del fenómeno se ha venido centrando en 4 temas: 1 . Origen de la primera cruzada. 2. Motivos por los se fueron a la cruzada. 3. Destino de esa primera cruzada, lo que muchos utilizan para determinar qué es cruzada y qué no. 4. Control de la Iglesia sobre el fenómeno. Nosotros añadiremos un quinto elemento a tener en cuenta. 5. Papel de la Península en el origen y desarrollo de la cruzada.

En los años 30 destacan los trabajos de 3 historiadores, considerados por todos como clásicos:

Carl Erdman es la linea de partida, aún hoy en día, de todo estudiante de las cruzadas. El punto básico de Erdman es el concepto de guerra santa, sancionada por la autoridad eclesiástica por una causa sagrada, y

65 En éste capítulo nos vamos a encontrar con tablas de historiadores. Cada historiador irá designado por su apellido, al que seguirá entre paréntesis, la fecha de edición de sus principales obras. 
su desarrollo, desde la alta Edad Media y remontándose a S. Agustín y su "bellum justum». Dicha evolución en el concepto de guerra santa entroncaría con la naciente caballería -el antiguo elemento militar germano-, que la iglesia «cristianizaría». El progreso de legitimización de la guerra santa tendría unos pasos bien marcados, aunque no fueran rectilíneos, especialmente desde el año 1000, y sería diferencial en el teatro de la Europa occidental con respecto a lo que pasaba en el imperio bizantino. Así mismo, su obra destaca la importancia que da a los símbolos externos: uso de insignias, banderas y armas santificadas, etc. Entiende la guerra santa como el combate de los caballeros en servicio de la Iglesia; en contra de otros opiniones, que le habían precedido y seguirían, que implicaban que sólo eran cruzadas aquellas que tenían un componente peregrino; es decir, las del Levante, considerando los otros hechos como no verdaderas cruzadas o aberraciones. Erdman, desde su concepción básica de cruzada como guerra santa rechaza ese punto de vista. Su trabajo se limitaba a analizar la idea de cruzada hasta la primera cruzada, y no entraba en otros campos como los de descrubrir los motivos por los que la gente iba. Erdman era partidario de que fue la Iglesia la conformadora de la idea de cruzada, a través de la evolución y asimilación de la concepción de la guerra santa. Iglesia encabezada por sus grandes reformadores: Gregorio I, León IX, Alejandro II y Gregorio VII. Para nuestro autor alemán, el motivo de la primera cruzada había sido la liberación de la iglesia oriental, es decir, responder a la demanda de ayuda de Bizancio. El papel de Jerusalén, consciente de su aumento de popularidad y como foco de atracción peregrina durante el siglo XI, sólo lo ve como un objetivo secundario y circunstancial, añadido por Urbano II porque conocía la atracción popular que producía la ciudad. De todo ello se desprende que Erdman no le daba tanta importancia a la peregrinación, como otros autores. Jerusalén sería el objetivo inmediato de la campaña, siendo la liberación de la iglesia oriental el objetivo d la verdadera campaña, de la guerra santa. En definitiva, Erdman entronca los movimientos de la Paz y Tregua de Dios, la reforma de la Iglesia, y la profesión militar para explicar esa última evolución en el concepto de guerra santa "ofensiva», que es la cruzada. Por otra parte, sí piensa que el papel de la Península fue importante para el origen y desarrollo de la cruzada, aunque sólo fuera como marco. De hecho, pone la campaña de Barbastro (1064) como el primer ejemplo de cruzada verdadera, llevada a cabo, eso sí, por cruzados extranjeros, franceses. Es más, la campaña de Tarragona (1089) se muestra como una cruzada que antecede inmediatamente e incluso se solapa en el tiempo (1098) con la primera cruzada oriental. Mientras que la polémica entorno a la calificación de Barbastro como cruzada sigue, y prácticamente 
se encuentra muy discutida ${ }^{66}$, el caso de Tarragona es más unánimemente reconocido. En cualquier caso, Erdman destaca que son cruzadas traídas por extranjeros, ya que los reinos peninsulares, salvo en momentos muy concretos, no llevaban a cabo una guerra santa ya que sólo había motivos políticos y económicos en esa primera etapa de la reconquista ${ }^{67}$. Además era inconcebible, por parte de los reinos cristianos peninsulares, una cruzada teniendo en cuenta la aculturación que existía, y los tratos que había entre cristianos y musulmanes que hacía que los reyes cristianos no estuvieran interesados en aniquilar a unos enemigos, que puede que un día se convirtieran en vasallos suyos. Es decir, algo parecido a lo que ocurría en Alemania y sus expansión hacia el Este. La situación en Italia, en el siglo xl, es diferente, donde las campañas contra los sarracenos, son entendidas como verdaderas guerras santas y protocruzadas; especialmente desde la unión de los Normandos con la Santa Sede $(1016,1049)$.

Delaruelle, que realizó sus investigaciones de forma completamente paralela a su contemporáneo Erdman, no pudo ver publicados sus trabajos hasta $1941^{68}$. Delaruelle también se preocupa de la evolución del significado y aceptación de la guerra, la guerra santa en la europa occidental, enfocándolo desde una historia de la vida religiosa y establece importantes conexiones con la liturgia y el arte. Afirma que para los participantes era una manera de ganar la salvación eterna. Destaca la importancia en la evolución del periodo Carolingio (como Erdman y aún más), y las épocas

66 Consultar las obras de Erdman, BoISSONNADE, C., «Cluny, la papauté et la première grande croisade internationale contre les sarrasins d'Espagne." Revue des Questions Historiques, 60 (1932): 257-301; DeforneauX, M., Les francais en Espagne aux XI et XIII siecles. París: 1949; BISHKO, C. "Fernando I, Cluny y Barbastro", Cuadernos de Historia de España (1968): 31-135; FERREIRO, A., "The siege of Barbastro, 1064-1065: a reassesment", Journal of Medieval History, 9 (1983): 129-144; ReYnaud, G., «La lutte Chrétienne contre le pouvoir musulman en Occident ou L'Origine ibérique de la Croisade d'Orient», Sharq al-Andalus, 8 (1991): 243-247; MARIN, M., "Crusades in the muslim West and the view of the arab writters", The Maghreb Review, 17 (1992): 95-102. [Sigue habiendo división de opiniones a cerca de las campañas de 1066, 1087, 1063 (Sicilia) y su influencia en la cruzada. Sobre Barbastro también hay divisiones: para Villey, Mayer o Noth no se puede considerar así; pero para Boissonade. Menéndez Pidal, Erdman o Mansilla sí lo es («Los autores tienden a apoyar la idea de que sí se puede considerar como cruzada, aunque no sea modelo de ella». BAC Historia de la Iglesia. II. Edad Media, p. 365. Madrid, 1984.]

${ }_{67}$ Ni en los reinos castellanos ni en el portugués: Erdman, C., A ldea de Cruzada em Portugal. Coimbra: Instituto Alemao, 1940. (Basado en «Der Kreuzzugsgegeclanke in Portugal» en Historisches Zeitschrift, 141 (1930): 23-53. Criticado en la Revista Portuguesa de Historia, I (1941): 305-311 \& XI (1962): 1-54).

68 Delaruelle, E., «Essai sur la formation de l'idée de Croisade.» Bulletin de Litterature Ecclesiastique (1941, 1944, 1953, 1954): 24-45 \& 86-110; 13-46 \& 73-90; 226-239; 50-63. (Hay una compilación de todos ellos bajo el mismo título, Turín, 1980.) 
inmediatamente posteriores, como la de Juan VIII, $915^{69} \ldots$ cuando se está estableciendo la "societas christiana». Con Gregorio VII la guerra santa se convierte en negocio de la nobleza, en todos los frentes, y no sólo de la realeza como antiguamente. Otorga la máxima importancia a Gregorio VII $\mathrm{y}$, especialmente, a Urbano II como verdaderos motores del cambio, de la integración de los laicos en la Iglesia.

R. Grousset, bizantinista por su parte, aporta dos ideas claves. 1) Las primeras «cruzadas» fueron en realidad las campañas de la Macedónica contra los musulmanes en el siglo $x$, entendiendo como cruzadas aquellas guerras “santas» sancionadas o bendecidas por la iglesia ${ }^{70}$; y 2) Introduce el tema colonialista, desde la perspectiva de los estados europeos occidentales como metrópolis -especialmente Francia- y los estados latinos de oriente como colonias. Tema querido por la escuela francesa (ex. Richard), tan radicalmente utilizado por la historiografía marxista (Zavarob) y lugar común de la historiografía judía (Prower, Kedar) y árabe. Es un tema que irá inevitablemente unido al estudio de las instituciones y vida árabe y que aún sigue de plena actualidad ${ }^{71}$.

Cliadro de cronología Historiográfica

A. 1. Erdman (1935) +++++++

2. Delaruelle (30's...1941-54) ++++++

3. Grousset (1934-36) +++++++++++++

4. Munro (1933-36 con Krey)

A.B 5. Fliche y Martín (1940-42/47)

6. Villey $(1942)+++++++++++$

7. Rousset (1945) ++++++++

B 8. Krey $(1948 / 1953)+++++++++++++++$

9. Richard (1953...1970/9) +++++++++

10. Cahen (1954...)

11. Alphandery (1954) ++++++++++++++++++

12. Runciman (1954) +++++++++++

13. Constable $(1953 / 1982 / 1985)+++++++++++++$

14. G. Gaztambide (1957)

69 Erdman, Noth o Brundage no lo creen así.

70 Grousset, R., Histoire des Croisades et du Royaume Franc de Jérusalem. 3 vols. París: 1934-1936. J. Norwich lleva la tesis a sus extremos al afirmar que las campañas del emperador Heraclio en el siglo vII fueron las primeras cruzadas. Norwich, J.J., Byzantium. The early centuries, p. 284. Londres: 1990 (1998).

71 The Horns of Hattin, ed. B.Z. Kedar, Jerusalem, 1992. (1987 conf.). 
Cuadro de cronología Historiográfica (continuación)

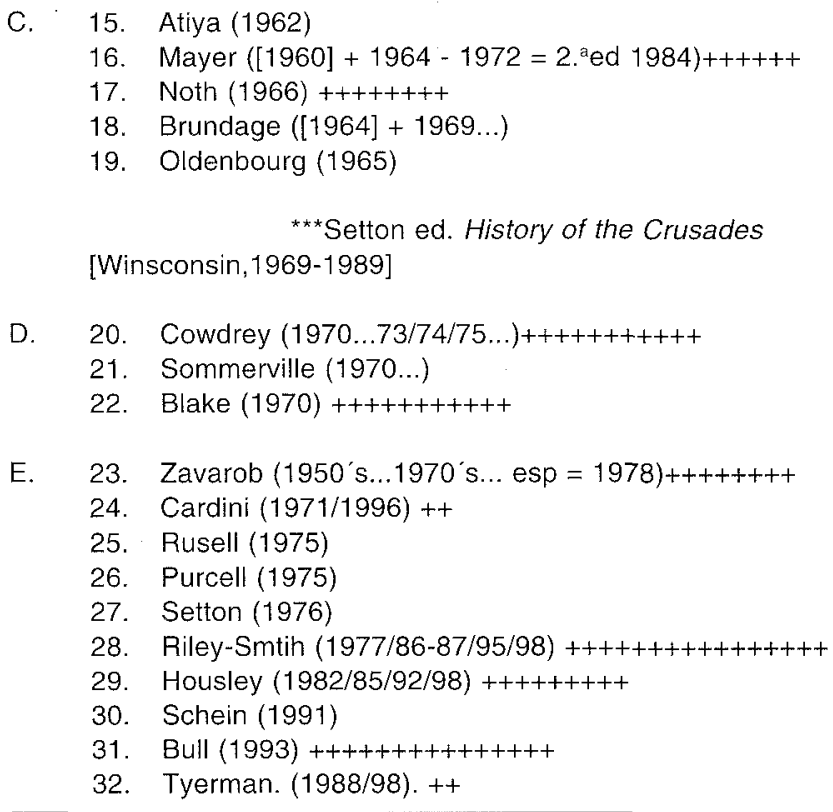

M. Villey ${ }^{72}$, va a ser el primero que se enfrente de manera sistemática con la plasmación jurídica del fenómeno cruzado. Entra en la evolución de la ideología cruzada y y su definitiva definición jurídica en el periodo posterior a la primera cruzada. Establece que la cruzada no es un problema fronterizo, y destaca la conexión entre Jerusalén como objetivo y el establecimiento de las indulgencias. Coincide con Erdman en los objetivos de la primera cruzada: La liberación de la Iglesia Oriental (Bizancio) y Jerusalén, pero otorga más peso a este último factor.

$P$. Rousset ${ }^{73}$ se va a mostrar más preocupado por la noción de cruzada a lo largo del tiempo, especialmente del siglo XII, y sólo considera tangencialmente el problema de los orígenes cuando habla en su capítulo de «Precruzadas». Se muestra contrario a Erdman que consideraba a las campañas italianas del XI como cruzadas, mientras que para Rousset solo se las puede considerar ejemplos de guerra santa,

72 VILLEY, M., La Croisade: Essai sur la formation de una theorie juridique, París, 1943.

73 RousSET, P., Les origines et les caracteres de la premiere croisade, París, 1945. Ver también, idem, «L'idée de Croisade chez les chroniqueurs d'Occident», $X$ Congreso de Science Storica, 547-564. 
no de cruzada. Rousset, al igual que Villey o Noth, se muestra en desacuerdo con la ecuación del alemán de cruzada como guerra santa, y exige más elementos para definirla. Constituye un ejemplo de historia ideológica y psicológica, aunque acabe poniendo el énfasis en el aspecto religioso.

J. Richard ${ }^{74}$, además de hacer una revisión de los anteriores autores cree que el tema de la confraternidad con los cristianos orientales es fundamental para entender la cruzada, junto con la atracción que ejercía Jerusalén. Atracción que se ve arropada por el desarrollo del movimiento peregrino y el instrumento de las indulgencias. Una vez dicho lo cual centrará su labor investigadora en los reino latinos de Oriente.

Alphandery y Dupront ${ }^{75}$ van a aportar un punto de vista antropológico al estudio de las cruzadas. Basándose en un estudio que pretende ser un análisis psicológico del movimiento, van a generar un gran debate en torno al la concepción popular de la cruzada. La ven como un movimiento colectivo, de masas, donde entran a formar parte elementos mesiánicos, milenaristas y escatológicos. Recalcan la importancia de la ciudad santa como centro de peregrinaje y el desarrollo de una actitud escatológica, destacando el sentimiento del pueblo. Su conclusión es que la primera cruzada fue un movimiento popular espontáneo centrado en Jerusalén, más que un proyecto oficial.

S. Runciman ${ }^{76}$, bizantinista y gran prosista, nos dejó una entrañable Historia de las cruzadas. Un libro muy ameno, riguroso y lleno de datos pero que no entra en el fondo del debate. No se decanta por una clara definición de cruzada, aunque queda claro a través de su obra que él sólo considera cruzada aquella destinada a Jerusalén. De hecho, casi la única verdadera cruzada sería la primera, aunque acepta las demás con destino a Tierra Santa. Por supuesto, es uno de los máximos valedores de la teoría «singularista», junto con Mayer. Como bizantinista destaca la importancia de las relaciones con la iglesia oriental, pero también es consciente de que el papa quería dar una proyección más amplia; entroncando con los temas de guerra santa y peregrinaje.

\footnotetext{
74 Richard, J., L'spirit de la croisade \& idem. The Latin Kingdom of Jerusalem, Oxford: 1979 (del original francés: Royaumme Latin du Jerusalén, París, 1953).

75 Alphandery, P., y Dupont, A., La Chrétienté et I'Idee de Croisade, París: 1954. 2 vol. Su última posición en Dupront, A., Le mythe de croisade. París: 1997.

76 Runciman, S., A History of the Crusades. Cambridge: 1951. (Hay traducción castellana: Historia de las cruzadas, 3 vols. Madrid: 1987.)
} 
G. Constable ${ }^{77}$ es uno de los primeros valedores científicos de la teoría «pluralista»; es decir, los que abogan por que se debe comprender a la cruzada en un sentido amplio, entendiéndola como toda aquella campaña proclamada por el papa como cruzada, por sus contemporáneos, hacia cualquier frente u objetivo. En su trabajo de 1953 demostró que las tropas de la segunda cruzada que luchaban en España, sobre el Elba y en Tierra Santa eran consideradas por sus contemporáneos como partes integrantes de una única hueste.

Mientras tanto, Atiya ${ }^{78}$ proclamaba, desde su visión orientalizante, que las cruzadas no habian sido más que una lógica conclusión y a la vez una manifestación más del tradicional enfrentamiento entre Oriente y Occidente. Es decir, sería la "solución franca al problema oriental».

Hans E. Mayer es otro de las piezas de toque del movimiento cruzado. En su trabajo publicado en alemán en 1965, pero que no alcanzó una amplia difusión hasta su traducción y primera edición al inglés en $1972{ }^{79}$ propuso una profunda revisión a las teorías de Erdman y enfocó el tema desde una visión «mercantilista» del fenómeno cruzado. Además reabrió el debate entre pluralistas, caso de Constable, y singularistas, su propia postura. Resaltaba también la influencia del elemento del peregrinaje, centrado en Jerusalén como foco de atracción. La visión mercantilista tenía dos esferas. Una material, por la que las personas buscan la formación de nuevos reinos o de riquezas. Otra es espiritual, en la que la cruzada, a través de las indulgencias, se constituiría para el hombre medieval como la mejor manera de ganarse el perdón de los pecados. Al igual que Erdman, para Mayer el principal objetivo de la cruzada era liberar y auxiliar a la iglesia oriental de los infieles sarracenos (cosa que fácilmente se podía extender al resto de los moros de Europa), rechazando la idea de que fuera Jerusalén el objetivo primordial ${ }^{80}$. Sin embargo, se distanciaba de Erdman al decir que si bien el objetivo oficial del papado había sido la liberación de la iglesia oriental, el asunto prontamente se le fue de las manos cuando el pueblo, de manera autónoma, instauró Jerusalén como

\footnotetext{
77 Constable, G., «The Second Crusade as seen by Contemporaries», Traditio, IX (1953): 213279. Recopilación de artículos en Constable, G., Monks, hermits and Crusaders. Variorum, 1988.

78 ATIYA, A.S., Crusades, commerce and culture. Bloomington: 1963.

79 MAYER, H.E., The crusades, Oxford,1984. 2. ${ }^{\text {a }}$ revisión. Del original alemán, Stuttgart, 1965, 1. ${ }^{a}$ revisión inglesa, Oxford, 1972. La segunda versión confirma sus originarias teorías aunque se hace eco de las novedades que se han producido en el campo del estudio de los estados del oriente latino.

80 En contra de Cowdrey que defendía el papel central del papado y Jesuralén como motivo primario.
} 
objetivo de la campaña y guerra santa. Es decir, no habría otro objetivo para una guerra santa, cruzada, más que Jerusalén. En este punto enlaza con las teorías escatológicas y milenaristas de Alphándery, principalmente entre la población más humilde; aunque para Mayer puede que el francés exagere un poco en sus conclusiones. Al igual que Erdman se muestra de acuerdo en asignar una importancia fundamental en el papel de la lucha en los reinos peninsulares como antecedente de la cruzada. Ese precedente no se encontrará en Barbastro, que sólo acepta como «protocruzada», sin llegar a dotarle del carácter que la otorga Erdman ${ }^{81}$; sino en el el episodio de Tarragona, aunque desde un punto de vista diferente al de Erdman. La guerra en España no sería una cruzada, aunque más tarde llegara a ser un sustitutivo de la cruzada. Los papas la promovieron y equipararon a la cruzada oriental; pero más que protocruzadas españolas eran sólo guerras santas, lo cual no es igual a cruzada ${ }^{82}$. Y, de hecho, no sería hasta el pontificado de Urbano II cuando se podría ver la influencia española en el desarrollo del concepto de cruzada. Cuando a la hora de enlazar con la gran importancia que daba él al elemento del peregrinaje, explicaba cómo las guerras en España (y, especialmente el episodio de Tarragona), habian contribuido al origen de la cruzada; como prueba de la evolución del peregrinaje en cruzada. Erdman ya hablaba de la importancia de Cluny en el desarrollo del concepto de guerra santa y peregrinaje armado, pero Mayer potenció esos factores, junto con motivos sociales y económicos, hablando de "vía de escape» a los problemas socio-económicos que afectaban a la clase caballeresca. En definitiva, Mayer, defendiendo esa teoría «singularista» llegaba a definir la cruzada apenas como una guerra cuyo objetivo era conseguir y/o mantener la dominación cristiana sobre el Santo Sepulcro en Jerusalén.

A. Noth ${ }^{83}$, en 1966 , volvía a poner sobre la mesa un antiguo debate. El de la identificación, o más bien, influencia del mundo musulmán sobre el cristiano occidental. Es decir, afirma, que el concepto de guerra santa y su plasmación en la cruzada en el mundo europeo responde a una influencia del modelo oriental de el yihad; así como las Órdenes Militares serían un reflejo o derivación del fenómeno de los ribat musulmanes. Curiosamente también ve el caso de Tarragona y el de la península ibérica como modelo para ilustrar su tesis.

81 De hecho al igual que Noth, niega que se opueda tener como evidencia la carta de Alejandro II sobre Barbastro como ejemplo de dirección papal o iniciativa.

82 En este punto se muestra de acuerdo con Villey y Rousset, en contra de Erdman.

$8 \mathrm{NoTH}, \mathrm{A}$., Heileger Krieg und Heileger Kampf in Islam und Christentum: Beitrage zur vorgeschichte der Kreuzzüge. Bonn: 1966. 
El estupendo trabajo de Blake ${ }^{84}$, en 1970 , demostró que la polémica que se había suscitado en torno al término y significado de cruzada era en parte artificial y en parte un problema meramente terminológico. Probó que a lo largo de la historia y las diferentes época el significado y características de la cruzada habían evolucionado y cambiado. Al igual que había habido diferentes motivaciones a lo largo de todo el movimiento. Para él no se puede hablar de cruzada hasta la primera, que fue la que posteriormente se adoptaría como modelo para las demás. En ella se unían la «guerra meritoria» y el «peregrinaje» (básicamente a los Santos Lugares). Todo eso se vería acompañado por un entusiasmo religioso y devocional, principalmente por parte del pueblo. Ello sería utilizado o acompañaría a la política papal que tendría como objetivo la unificación de las iglesias. De ahí que de importancia al tema de las indulgencias y los santos lugares como conformadores de la cruzada, que responde a una política papal; teniendo, como ya se ha dicho, la primera cruzada como modelo. También tenía en cuenta el tema de la Paz y Tregua de Dios, la cristianización de la caballería y los casos en España, todo ello como pasos previos, aunque no conformantes, de lo que sería la cruzada. Sobre las motivaciones para asistir a ella podríamos encontrar una mezcla de razones de índole económico, social y religioso que, por supuesto, variarían entre diferentes tipos de población y épocas históricas.

A. Waas ${ }^{85}$ también resaltaba la calidad religiosa del movimiento - destacando la importancia fundamental de la predisposición religiosa del caballero como «vasallo de Dios»-, atacando la concepción colonialista de Grousset y la visión secularizante de la obra iniciada por Setton ${ }^{86}$. Sólo valen esa espiritualidad del pueblo y de la nueva caballería; el resto de los elementos son secundarios como caracteres conformadores de la cruzada.

Zavarob es uno de los máximos exponentes de la postura marxista, si bien no es el único ${ }^{87}$. Su obra, traducida a casi todos los idiomas ${ }^{88}$, destaca los condicionantes socio-económicos, despreciando cualquier motivación o importancia de elementos religiosos. Zavarob nos pinta una situación en la que durante todo el siglo $\mathrm{xI}$ se han venido produciendo fuertes tensiones sociales, tanto horizontales como verticales, ya que los

84 BLAKE, E.O., "The Formation of the Crusade Idea." Journal of Ecclesiastical History,21 (1970): 11-31.

${ }_{85}$ WaAs, A. Geschichte der Kreuzzüge, 2 vols., Frieburg: 1956.

es A History of the Cusades, Hazard \& Setton ed, VI Vols, Winsconsin, 1969-1989.

87 Por ejemplo, Werner, W., Die Kreuzzugsidee im Mittelalter, 1958.

88 Inluido el español, Zavarob, M., Historia de las Cruzadas, Madrid: 1978. 
plebeyos («proletari») siguen en la servidumbre. La cual se acentuará debido al auge del comercio y las ciudades, que no hacen más que alimentar el ansia de lujo, lo que, a su vez, hace aumentar la presión señorial sobre ellos. De ahí se generaría una «lucha del proletario contra la opresión señorial', bien activa (rebeliones... frecuentemente apoyadas en herejías), bien pasivamente (fuga de las tierras, herejías e incluso la peregrinación). Por otra parte, la clase preponderante también sufriría tensiones internas por la pérdida de los pequeños propietarios y la creación del mayorazgo; dando lugar a un excedente de nobleza que se dedicaría a la violencia, de la que saldría muy dañada la Iglesia. De ahí que la Iglesia, como garante del régimen feudal, intente proteger, además de justificar, el sistema feudal procurando solucionar los dos problemas: de una parte imponiendo un control ideológico, de otra instaurando una paz europea, a ser posible expansionista. La guerra sería orientada hacia el oriente tanto por motivos económicos (riquezas) como políticos (control de la Iglesia oriental). De ahí toda la idea de cruzada. No obstante admite cierto carácter religioso en las primitivas peregrinaciones, aunque con ese perfil de resistencia pasiva al sistema; así como en el punto en el que argumenta que la iglesia aprovechó el fanatismo religioso de las masas y la petición de auxilio de Bizancio para lanzar el ataque.

Tanto Riley-Smith, desde sus trabajos sobre orígenes y desarrollo de la primera cruzada ${ }^{89}$, como N. Housley, desde los suyos sobre las cruzadas en Italia y las últimas cruzadas, son los máximos valedores, hoy en día, de la teoría "pluralista». Como explica Riley-smith a lo largo de sus obras, la pregunta básica que se hacen los defensores de la tesis pluralista es ¿qué es lo que lo que los propios contemporáneos pensaban de las cruzadas? ¿Qué es lo que ellos consideraban cruzadas? Contestando a estas preguntas y haciendo uso de otras fuentes a las que no solían hacer referencia los singularistas es como responden los pluralistas. Para ellos hay claras muestras de que las gentes que vivieron esos momentos - tanto desde el papado como desde las cortes o el común del pueblo- consideraban cruzadas aquellas otras campañas santificadas por Roma que no solo eran dirigidas a Tierra Santa. Otra cosa es que se admitiera una cierta preeminencia del objetivo Jerusalén, que cada teatro tuviera sus particularidades

89 RILEY-SmitH, J., The Crusades: a short History. Londres: 1987. - The First Crusade and the Idea of Crusade. Pensilvania: 1986. - What were the Crusades? Londres: 1977. — «The Crusading Movement and the Historians", The Oxford lliustrated History of the Crusades, 1-12, J. RileySmith, ed. Oxford, 1995. - The First Crusaders, 1095-1131. Cambridge: 1997. HousLEY, N. The Italian Crusades. Cambridge: 1982. - The Later Crusades, 1274-1580: from Lyons to Alcazar. Oxford: 1992. 
diferenciales y semejanzas, o que hubiera críticas hacia cómo el papado hacía uso de dicho instrumento, así como sobre ciertas cruzadas puntuales. Tanto Riley-Smith, como Housley y los demás pluralistas aceptan por extensión que, por lo tanto, el término cruzada no se puede limitar a un marco geográfico o cronológico. Por ello también entienden como cruzadas aquellas otras que tuvieron lugar en los teatros Bálticos, peninsular y europeo, tanto contra sarracenos, infieles, paganos o enemigos de la iglesia. Así mismo, el término cruzada se extendería desde el siglo xI hasta las campañas de los siglos XIV-XV e incluso el siglo XVI, contra turcos y otomanos. Todo ello en oposición a los singularistas, además de aquellos que sólo aceptan como cruzada únicamente a la primera, que limitan el período cruzado hasta el final de la existencia de los reino cristianos latinos en oriente, 1291; aceptando todo ellos una clara decadencia del ideal de cruzada ya para mediados de dicho siglo.

Antes de que J. France ${ }^{90}$, através de la historia militar, volviera a destacar la importancia del elemento bizantino, o la aportación bizantina a la primera cruzada, Bull había sido el último en revolver el, por otra parte, nada tranquilo mar de las cruzadas. Su libro, desde preceptos de un estudio regional, llega a una serie de conclusiones revisoras (especialmente de Erdman) e innovadoras por una parte y contestatarias por otra ${ }^{91}$. Si bien en muchos aspectos, sobre todos relacionados con el papel de ciertas zonas de Francia en el movimiento cruzado y su aguda percepción de los mecanismos de transmisión de propaganda, motivación y reclutamiento, es considerada y admitida sus teoría, en otros ha recibido una pronta respuesta. Tal es el caso de el papel que él otorga a la península ibérica en el origen de las cruzadas. Para Bull dicho papel es inexistente, ya que las campañas francesas en la península sólo buscaban el botín económico. De esa manera, y aunque con un enfoque distinto, sigue las teorías de Fletcher o Deffourneaux, que así mismo negaban cualquier papel de los reinos cristianos peninsulares en el origen y desarrollo de las cruzadas (al menos hasta la segunda mitad del siglo XII). Sin embargo, dicha postura ha sido ya contestada por autores como el propio Riley-Smith ${ }^{92}$, Housley ${ }^{93} \mathrm{o} \mathrm{J}$. France ${ }^{94}$, que

\footnotetext{
90 France, J., Victory in the East, Cambridge: 1994. Contrastar con el reciente libro de J. Philips al respecto (1997).

91 BuLL, M., Knightly piety and the lay response to the First Crusade, Oxford, 1993.

92 RILEY-SMITH, J., «Carl Erdman. Sixty years later», Jornadas Internacionales sobre la Primera Cruzada, Madrid: 1998, pp. 17-29.

93 HOUSLEY, N., «Frontier societies and crusading in the later middle ages», Mediterranean Historical Review, 10 (1995): 104-119.

94 France, J., “Les origines de la premiere croisade: un nouvel examen», Autor de la Premiere Croisade, 43-56. Balard, Paris, 1996.
} 
vuelven a abogar por la importancia del escenario y reinos peninsulares, no sólo en el origen de las cruzadas; sino también en su desarrollo, evolución y pervivencia.

En el última trabajo de J. Riley-Smith ${ }^{95}$ el autor vuelve a argumentar en contra de las teorías que ven en el colonialismo, la búsqueda de ganancias materiales o el aumento demográfico y la presión sobre las familiares nobiliarias la razón del origen o éxito de respuesta de la primera cruzada. Basándose en un estudio prosopográfico de una lista de cruzados que ha logrado identificar para dicho período llega a las siguientes conclusiones. Destaca la importancia del peregrinaje y el creciente culto a santuarios durante el siglo XI; peregrinaje que venía tomando como objetivo Jerusalén. Dicho peregrinaje se transformó en peregrinaje armado gracias a la actitud de los papas, especialmente Gregorio VIII (que también desarroIlaría el tema como causa justa y meritoria), aunque no fuera hasta con Urbano II cuando se diera el elemento característico y diferenciador de la cruzada; siendo esta un peregrinaje armado fusionado a una guerra penitencial. Por lo tanto para Riley-Smith el momento crucial para el origen de la cruzada se produce entre 1080 y el 1095 . Descarta la lucha en la península ibérica como fuente originaria de la cruzada y por supuesto no considera que la campaña de Barbastro tenga nada que ver con una cruzada, ni siquiera en forma de embrión (algo parecido a lo que opinaban Fletcher y Bull). Sin embargo, sí le otorga importancia a este escenario como creador de un ambiente de conflicto a los que bastantes caballeros y familias francesas ya estaban acostumbrados o tenían noticia de ello, y vuelve al episodio de Tarragona (1089) como el primer sitio donde se muestra ese elemento que para Riley-smith es característico: la unión del concepto de peregrinación con la idea de una guerra penitencial por la remisión de los pecados ${ }^{96}$. Sin embargo, el principal objetivo de este trabajo era demostrar la importancia fundamental que habían tenido los lazos de parentesco entre las familias riobiliarias del occidente europeo y sus obligadas relaciones de vasallaje para explicar parte del éxito de respuesta de esta primera cruzada ${ }^{97}$.

Llegados a este punto, la postrera obra de Tyerman nos hace replantear muchas cosas. En 1998 publica un pequeño libro en el que entra a

95 RILEY-SMITH, J., The first Crusaders, 1095-1131. Cambridge Univ. press., 1997.

96 Riley-Smith, J., The first Crusaders, 1095-1131. Cambridge Univ. press., 1997, p. 52.

97 Este trabajo habría que mirarlo comparándolo con los de Bull, France, Mayer y Tyerman anteriormente citados. Por lo visto una de las discusiones más acaloradas durante el último congreso de la SSCLE en Jerusalén, 1999, fue sobre el número y la calidad de los participantes en la primera cruzada. 
fondo en el problema de hasta qué punto la cruzada es una «invención moderna». Repasando todos los temas -y terminología- clave de las cruzadas tiende a apoyarse en el evolutivo elemento popular como conformizador de las mismas. Pero, básicamente, su libro es una llamada de atención para enfocar el problema desde otros puntos de vista ${ }^{98}$.

1.2.1. El papel de la Historiografía española sobre las cruzadas. Castellanos, hispanistas y el desconocimiento mutuo

"La cuestión del carácter religioso de la Reconquista española nos parece poco estudiada... El estudio de la aplicación a España de la forma de la cruzada no ha sido hecho todavía."

- VILLEY, M., La Croisade. Essai sur la formation d'une théorie juridique. París, 1942, 63, nota 155; 193.

"Ai colleghi spagnoli domandiamo uno studio attento sui legami fra crociata in Terrasanta e "Reconquista" sa sul plano delle idee sia aquello dei fatti."

- Cardini F., «La storia e l'idea de crociata negli studi odierni (19451967)", Anuario de Estudios Medievales, 5 (1968): 641-662.

Estas dos citas, separadas entre sí por 28 años, representan casi hasta la actualidad cual es el panorama del estudio de las cruzadas desde, y, en la península. Ciertamente, salvando las dos honrosas excepciones de Goñi Gaztambide y Benito Ruano, cuyos trabajos se centran en los años 50, y unas cuantas obras de divulgación, el panorama ha sido completamente desolador, al menos hasta 1995. Es ahora, y a raíz de las conmemoraciones de la predicación de la primera cruzada, cuando parece que los investigadores hispanos muestran más interés por el tema ${ }^{99}$.

Quizás habría que matizar. Podemos decir que la situación, en general, es bastante penosa para toda la península y especialmente lamentable para el caso de la corona de Castilla. Los reinos de la corona de Aragón y Navarra, probablemente por la amplia proyección internacional de ambos

s8 TyERMAN, Ch., The Invention of the Crusades, Toronto: 1998. Un capitulo de dicho libro es: "Were there any Crusades in the 12th century?", English Historical Review, 110 (1995): 553-577.

99 Por cierto, Benito Ruano fue el único representante español al $X$ Congresso di Science storiche, Firenza, 1955, dedicado al estudio de la idea de cruzada. Desde ese momento no ha habido ninguna participación nacional en un congreso internacional sobre las cruzadas hasta 1995, fecha en la que se organizaron las Jornadas Internacionales en Madrid, ya mencionadas, mientras que yo mismo asistía al congreso de la SSCLE en Clermont-Ferrand ese mismo año. 
desde fines del siglo XII hasta su unión con el reino de Castilla, se han visto más favorecidos en cuanto al número de estudios y estudiosos dedicados a ellos ${ }^{100}$.

Actualmente no estoy en condiciones de realizar una crítica general del caso portugués, aunque dudo mucho que sea algo mejor que el del castellano ${ }^{101}$. Sin embargo sí me gustaría llamar la atención sobre la última aportación en lengua portuguesa sobre el tema. Se trata del trabajo del profesor Da Costa. Éste, que también partió del estudio de las Órdenes Militares - la del Hospital - se destaca la continuidad de una mentalidad cruzada, con características propias, al menos desde el siglo XII hasta el XV en la península ibérica, aunque por supuesto, se centra en el caso portugués. Mentalidad muy ligada al desarrollo de un código de nobleza-caballeresco, y donde la monarquía tiene un papel importante en su preservación ${ }^{102}$.

Por otra parte, parece que la temática ha suscitado mayor interés para los hispanistas (Burns, Lomax, Forey, Dufourq, O'Callaghan, Bishko, Linehan, Hillgarth, entre otros) e historiadores extranjeros (como N. Housley), que para los propios nacionales que, a mi entender, y hasta fechas muy recientes, han tenido una visión muy aislacionista o excepcional del caso hispano ${ }^{103}$. Otra cuestión es el que historiadores extranjeros, con poco o ningún conocimiento de las fuentes o el trabajo que se realiza en la península, se pongan a lanzar hipótesis o diatribas al respecto; algo que tampoco es raro y de lo que encontraremos algún que otro ejemplo en el presente trabajo.

100 Por citar sólo un clásico ejemplo: GuNTA, F., Aragoneses y catalanes en el Mediterráneo, Barcelona: 1989. t. $^{\text {a }}$ revisión, 1972 de la obra original en italiano, en 1959.

101 Rodríguez García, J.M. «Relaciones cruzadas entre Portugal y Castilla, 1252-1292». As relaçoes de fronteira no século de Alcanices. Actas das IV Jornadas Luso-Españolas de Historia Medieval, pp. 945-55. Vol. II. Oporto, 1998.

102 SilveiRA DA COSTA, R.L., A guerra na idade media. Un estudio de mentalidade de Cruzada na Península lbérica. Río de Janeiro, 1998. Asimismo, y aunque sólo sea de forma parcial y fuera ya de época, merece la pena citar el artículo de SIDARIUS, A, «Le "Livro da Corte Enperial" entre l'apologétique luliiene et l'expansion catalane au XIVe siècle», Diálogo folosófico-religioso entre cristianismo, judaismo e Islamismo durante la Edad Media en la península Ibérica", 131172, Brepols, 1994. También los trabajos de Bolsselier, A., como "Reflexions sur l'ideologie portuguese de la Reconquete, XIl-xive siecles", Melanges de la Casa de Velázquez (1994): 139165.

103 Un ejemplo de lo que esperamos sea una tendencia continuada de contextualización internacional es Rodriguez López, A., La consolidación territorial de la monarquía feudal castellana: expansión y frontera durane el reinado de Fernando III, Madrid: 1994. Trabajo en el que, a mi entender, aunque no se llega a dibujar bien las interrelaciones a todos los niveles del fenómeno, al menos se hace un serio intento de contextualización histórica. 
Dejando atrás la historiografía más tradicional española, que identificaba totalmente la Reconquista con la cruzada (ya trataremos más adelante los problemas de definición), y coincidiendo con el «boom» de la década de los cincuenta ${ }^{104}$, en España nos encontramos con un conjunto de obras como las de Goñi, y Benito Ruano (éste último centrado en el campo de las Órdenes Militares); a las que se podrían sumar las de Antelo Iglesias y Sobrequés, más quizás alguna de Asensio ${ }^{105}$, que tratan aspectos parciales de la problemática, y que son aún punto de referencia. En los años 70 nos encontramos con obras de divulgación de M. A. Ladero, J. L. Martín y A. Cortazar ${ }^{106}$. Los cuales, desde su conocimiento enciclopédico, apenas aportan nada nuevo, aunque sí en su campo como especialistas en el siglo XV (Granada) y las Órdenes Militares. Últimamente, dejando aparte otro par de obras o manuales de difusión y síntesis ${ }^{107}$, y también desde el campo de las Órdenes Militares, podríamos señalar los trabajos de Ayala y Guijarro en el mismo sentido ${ }^{108}$.

De hecho, para Castilla, hasta éste último año era de obligada y única referencia el gran trabajo de Goñi Goztambide sobre la bula de la cruzada en España, y los otros pequeños, aunque interesantes y dispersos, artículos de Benito Ruano o el último trabajo de García-Guijarro (los dos últimos refiriéndose básicamente a las implicaciones entre las Órdenes Militares y el ideal cruzado). A parte de los mismos, poco más se puede decir en el ámbito de estudios medianamente profundos. Sin embargo, en estos cuatro últimos años, parece que el tema cruzado ha experimentado una especie de tímida revisión y resurgimiento en la historiografía española sobre el reino de Castilla. Al presente trabajo, se le pueden unir las ya mencionadas comunicaciones de F. Valdés y otras ${ }^{109}$, o las jornadas ce-

104 Junto con las importantes obras que vieron la luz en esta década, también cabe destacar la celebración del ya mencionado Congreso de Firenza de 1955, y la creación de un grupo de investigadores de las universidad de Oxford que se encargarían del estudio de las Ordenes Militares en la península, cuyos miembros eran A. Forey, D. W. Lomax y A. Lutrell.

105 Sobreques VIDAL, S., «Sobre el ideal de Cruzada de Alfonso V de Aragón». Hispania, 12 (1952): 232-252; ANTELO IGLESIAS, A., "El ideal de Cruzada en la Baja Edad Media peninsular». Cuadernos de Historia, I (1967): 37-43. (Madrid, 1968); Asensıo, E., “¡Ay, Jerusalén. Plantío narrativo del siglo XII»», Nueva Revista de Fllología Hispánica, 14 (1960): 247-270.

106 Martín Rodriguez, J.L., Las Cruzadás, Cuadernos de Historia 16, 140, 1985; Ladero QueSAdA, M.A., Las Cruzadas. Bilbao: 1972; García de Cortazar, J.M., y Ruiz de AguiRre, Las Cruzadas. Bilbao: 1966. (Bruguera, F., Las Cruzadas. Barcelona, 1975.)

107 LASTE, M.A., Las Cruzadas, Madrid, 1991. Isidre BuRunat, S.J., Les grans Croades Medieval, Barcelona, 1992.

108 Ver bibliografía, más: Ayala MARTíNEZ, C. de, «Hacia una comprensión del fenómeno cruzado: las insuficiencias del reduccionismo económico». La primera cruzada 900..., pp. 167-195; GaRCíA-GulJARRO RAMOS, L., «Expansión económica medieval y cruzadas», La primera cruzada 900..., pp. 154-166.

109 Rodriguez Garcia, J.M. «Idea and reality of crusade in Alfonso X's veign, 1252-84». Autour..., pp. 379-99; idem, «Fronteros y cruzados. Discusión sobre el carácter cruzado de la guerra en la 
lebradas en Madrid sobre el Concilio de Clermont. El postrer trabajo que ha visto es la tesis doctoral de la Dra. Ana Echevarría, sobre la predicación cruzada en el siglo XV ${ }^{110}$.

Goñi es el autor de partida. Sin embargo, como él mismo dice de su obra: «...nos ceñimos a historiar la Bula de la cruzada en España, dejando a un lado su aplicación a los reinos y dominios extrahispánicos sometidos a la corona española. No entraba dentro de nuestros planes exponer la evolución del organismo administrativo de la cruzada ni la historia de las otras rentas eclesiásticas - subsidio, excusado, décima, tercias, venta de vasallos- si bien no faltan aquí y allá algunas indicaciones» ${ }^{111}$. Es decir, que su estudio que abarcaba desde el siglo XI hasta el Xix iba ser forzosamente generalista, siguiendo la trayectoria simple de las promulgaciones de la Bula de cruzada para España. Él, a su vez, basaba su estudio en la documentación pontificia sobre dicha bula (Archivo Vaticano), así como en las fuentes cronísticas, el Archivo de la cruzada (situado en su momento en Toledo) y el Archivo de Simancas. Su obra, desarrollada entre 1940 y 1955 -y por lo tanto solo accesible a la bibliografía publicada hasta dicha fecha-, aunque dada a la luz a finales de 1957, vino a paliar, al menos en parte, el vacío de la historiografía española tanto sobre la cruzada en general como la significación de la Reconquista dentro de ella, tema central de su estudio. Él mismo reconocía que no había hasta la fecha ningún trabajo sobre ello, en ninguno de los campos, tanto en la implicación de españoles en cruzadas extrapeninsulares - que él tampoco trata ${ }^{112}$, como en la evolución de la fiscalidad, desarrollo de ideología cruzada, mecanismos,... o la propia interconexión entre Reconquista y cruzada ${ }^{113}$.

en la fontera». III Estudios de Frontera, pp. 569-586. Jaén, 2000; GonZÁleZ JIMÉnEZ, M. «Idea y práctica de cruzada en la España Medieval: las cruzadas de Alfonso X". $V$ Jornadas de Historia Militar, pp. 171-186. Sevilla, 1997; TORRES SEVILLA-Quiñones, M. «Cruzadas y peregrinos leoneses y castellanos en Tierra Santa, ss. XI-XII», Medievalismo, 9 (1999): 63-82; MEYER, B. «EI papel de los cruzados alemanes en la reconquista de la península Ibérica». En la España Medieval, 23 (2000).

110 Echevaría Arsuaga, A., "The Fortress of Faith»: the Perception of Muslims in XVth century Spain». Brill: 1999. A última hora ha llegado a mi conocimiento otra interesante tesis aún en elaboración: DomínGuez, C., "La Gran Conquista de Ultramar en el marco de las Cruzadas», Univ. de Santiago de Compostela.

111 Goñı Gaztambide, J., Historia de la Bula de la Cruzada en España. Vitoria: 1958, p. X.

112 Apenas si podía mencionar a FERnández de NAvarRete, M., Españoles en las Cruzadas (Discurso de Ingreso en la Real Academia de la Historia, 1815). Madrid, 1986.

113 Señalando sólo, entre los manuales, a Garcia de Valdeavellano, L., Hitoria de España, l: De los orígenes a la Baja Edad Media, Madrid, 1952. Así mismo citaba las palabras de Villey: «La cuestión del carácter religioso de la Reconquista española nos parece poco estudiada... El estudio de la aplicación a España de la forma de la Cruzada no ha sido hecho todavía» (VILLEY, M., La Croissade. Essai sur la formation dúne théorie juridique, París, 1942, pp. 63 y 91. 
Desgraciadamente, después de esa obra no se ha hecho mucho más. $\mathrm{Ni}$ siquiera contamos con obras compilatorias de investigación propia, aunque no podemos olvidar los trabajos, ya citados, de carácter divulgativo de Ladero Quesada o Jose Luis Martín, junto con los últimos manuales de Burunet y Laste o la aportación sobre Órdenes de García-Guijarro.

Si son inexistentes los estudios generales, en cuanto a las «tradicionales cruzadas» en Levante o Báltico, también lo son los estudios específicos para el caso castellano, salvo algunos cuantos, que como ya hemos visto, tienden a centrarse en la relación entre Órdenes Militares y cruzada o Reconquista, tanto dentro como fuera de nuestras fronteras. Hay una total falta de trabajos españoles sobre las cruzadas en oriente, báltico o cualquier otro escenario, o incluso sobre la participación de españoles fuera de nuestra península. A este respecto cabría hacer la excepción en cuanto se refiere a dos importantes temas: Por un lado la presencia Aragonesa en el Mediterráneo Oriental -durante el final del siglo XIII y el siglo XIV-, y, por otro, la "cruzada» hispana del siglo XVI en su vertiente Mediterránea y Europea así como la exportación de su mentalidad a la conquista de América ${ }^{114}$. Por lo tanto nos es imposible realizar un estudio historiográfico del mismo tema, es decir, de las cruzadas fuera de la península. El único tema historiográfico que hemos visto anteriormente, y que podría haberse tratado de una forma indirecta por los histuriadores españoles es el de la fiscalidad cruzada, elemento importante dentro de la corriente historiográfica del «home front» 115 .

Otra cuestión es cuando descendemos al estudio de nuestra reconquista como fenómeno cruzado. Podemos decir que los trabajos en los que al menos se tiene presente el tema cruzado se centran en los estudios de reyes especialmente predispuestos para ello; a saber, reyes que tradicionalmente se les ha otorgado un carácter «cruzado», muchas veces sin

114 Ver en Cristina González... Cammings, 1976, Rodríguez Prampolini, 1948; Leonard, I.S., Los libros de los Conquistadores, Buenos Aires, 1953.

115 Sabemos que el papel agilizador en la evolución de la fiscalidad gracias a las exigencias de recaudación cruzada es uno de los principales líneas de investigación dentro del «estudio de la retaguardia», así como el de reclutamiento, propaganda, etc. Ya Torres Fontes reconocía que el estudio de dicho tema en el ámbito peninsular era algo difícil de distinguir debido a que en la cruzada o campañas cruzadas en el ámbito peninsular era imposible de discernir entre frente y retaguardia, siendo una sociedad de frontera; aún reconociendo el impacto de dicho elemento de confrontación, especialmente desde 1266 (TORRES FONTES, J., «El diezmo eclesiástico en Sevilla y Murcia en el siglo XIII», Alfonso X: Vida, obra y época, Madrid, 1984). Un ejemplo de cómo se ha venido acercando a dicha problemática es el aséptico estudio de Nieto SoRIA, J.M., Iglesia y poder en Castilla. El episcopado (1250-1350). Madrid, 1988 (ver capítulo dedicado a las rentas eclesiásticas). Por otra parte, hay todo un nuevo conjunto de estudios que tratan la problemática de «la frontera» [PĖREZ DE TUDELA, M.l., "El concepto de frontera en la historiografía medieval hispana». Castellum, 2 (1991): 131-140]. 
entrar en razonamientos adecuados o más profundos y científicos: Alfonso VI, Alfonso VIII, Fernando III, Alfonso XI y, especialmente, los Reyes Católicos. Y como periodo cronológico, parece haber bastante más trabajos para el periodo de los siglos XIV y XV que para el resto.

Para el siglo XIII castellano, basta echar un ojo a la bibliografía. Los estudios se centran en la campaña de las Navas y en el reinado de Fernando III, al que su moderno biógrafo, González, Ilama «prototipo del rey cruzado» ${ }^{116}$. Aún así, no hay ningún estudio específico sobre el ideal cruzado en Castilla, en dicho siglo. Ni siquiera las obras de dos personajes peninsulares con una reconocida importancia dentro del mundo cruzado, como son Raimundo de Peñafort, Ramón Martí y Ramón LLull, han merecido un estudio u obra específica al respecto por parte de historiadores peninsulares, si bien es cierto que las obras sobre el último están proliferando ${ }^{117}$. De Alfonso X se apuntan algunas ideas (n. 109).

Historiográficamente, los historiadores españoles han olvidado las cruzadas fuera de nuestra península. Pero quizás, lo más preocupante sea la tendencia a aislar el fenómeno cruzado, de la reconquista, cualquiera que sea su definición, como ya veremos. Sobre éste punto, la relación historiográfica entre cruzada y reconquista, así como sus propias percepciones tratará el siguierite apartado.

\section{Un problema historiográfico: cruzada y reconquista. Diferentes concepciones. Posibles influencias}

La discusión de la propia definición de Reconquista ha sido una constante en la historiografía española desde fines del siglo pasado. De hecho aún hoy en día se sigue discutiendo alrededor de las teorías de Sánchez

116 González González, J., Reinado y diplomas de Fernando III. Córdoba: 1980-84, p. 78.

117 Aún así se pueden ver algunos apartados dentro de las obras de: para R. Peñafort: BRUNDAGE, J.A., Medieval Canon Law and the Crusades. Madison: 1969; RusselL, The Just War in the Middle Ages. Cambridge: 1975. Para R. Martí: LAVA.Jo, J.C., Cristianismo e islamismo na Península Ibérica (3 Vols.) Vol. II. «Raimundo Martí, un precursor del diálogo religioso». Tesis doctoral, Universidad de Evora, 1988. Para R. Llull: KedAR, B.Z., Crusade and mission, Princeton, 1984, pp.189-194; HiLlGARTH, J.N., "The attitudes of Ramon Llull and Alfonso X of Castile to Islam». Actas del V Congreso Internacional de Filosofía Medieval, 825-30. Madrid, 1979; DANIEL, N., "Crusade Propaganda», A History of the Cusades, 39-97, Hazard \& Setton ed., vol. VI,

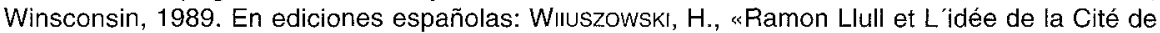
Dieu. Quelques nouveaux écrits sur la Croisade», tirada aparte de Miscelánea LLulliana, ed. especial en el VII centenario de su nacimiento, Barcelona, 1950, pp. 87-110 y OLIVER, A., "El "Ilibre de la la Orde de Caballeria" de Ramón LLull y el "De Laudae Novae militiae" de San Bernardo", Estudios Llullianos, // (1958): 1-13. Más, en general: GoÑl GAZTAMBIDE, Historia de la Bula de la Cruzada en España, Vitoria, 1958, pp. 235-262. Bien es verdad que en los últimos 3 ó 4 años se 
Albornoz, Menéndez Pidal y Américo Castro sobre qué es lo que pasó en nuestra Edad Media, por ende qué es nuestra Reconquista y en qué se parece o diferencia con lo que ocurre en el resto de Europa (léase las cruzadas); todo ello en torno al debate de qué es España y quienes son los españoles ${ }^{118}$.

A nuestro entender este debate debe ser superado. Pero teniendo en cuenta que a pesar de todo aún sigue vivo, que es lo que básicamente se conoce fuera de la península sobre la discusión historiográfica en España ${ }^{119}$ y que, sin lugar a dudas, constituyen un meritorio punto de partida, por todo ello no podemos dejar de dar unos retazos sobre dicho debate y las opiniones derivadas que realmente nos interesan.

El caso es que en todo este debate no es hasta mediados de la década de los cincuenta cuando en la historiografía hispana se distingue claramente entre guerra santa y cruzada, conceptos que como ya veremos son diferentes, por lo que el debate en torno a la polémica cruzada/reconquista es todavía más obscuro. A pesar de la declaración de Dozy a mediados del siglo XIX afirmando que lo que había existido en la península durante la Edad Media nada tenía que ver con nación o religión, la postura peninsular hasta la década de los 70 fue todo lo opuesto. Aunque había evidentes diferencias que separaban a M. Pidal de G. Pelayo ${ }^{120}$, lo cierto es que, tanto descle la visión más religiosa/ideológica de Pidal, como la más materialista de Pelayo, al final se admite una general identificación entre "cruzada» y «Reconquista». El problema es que ninguno de ellos define lo que es exactamente una cruzada. La tesis de una reconquista en la que se lucha de manera conjunta por la religión y la nación será la mantenida por Villada y otros autores ${ }^{121}$. Benito Ruano y G. Goztambide también comparten la preeminencia del ideal religioso en la lucha de los reinos cristianos en la reconquista, visión que recogerá G. Villoslada en su historia de la Iglesia ${ }^{122}$.

están multiplicando los trabajos sobre R. Llull. Por ejemplo ver Iberia and the Mediterranean World. Studies in honour of , I. Burns. (Kalamazoo, 1995-1996), Brill, 1997-8; O R. LLULL, Alguns escrits sobre la croade. Traducció del Petitio Raymundi pro conversione infidelum... Barcelona, 1997.

118 El úlitimo ejemplo de dicho debate se puede encontrar en: España. reflexiones sobre el ser de España. Real Academia de la Historia. Madrid, 1997; Recuero Astray, M.J. Orígenes de la Reconquista en el occidente peninsular. La Coruña, 1996.

119 Para una discusión historiográfica actual vease, LINEHAN, P., History and Historians of Maedieval Spain, Oxford, 1993.

${ }_{120}$ Éste último tenia una visión mucho más laicizante de la lucha que se había producido en la península, en la que la principal razón de ella había sido la adquisición de inmediatas realidades materiales.

121 Sobre toda esta polémica historiográfica se puede consultar LINEHAN, P. History and Historians of Medieval Spain. Oxford, 1993, cap. 7.

122 Villoslada, dir., Historia de la Igiesia de España, t. II, Madrid, 1982. 
La gran diferencia es que estos último autores ya distinguen claramente lo que es guerra santa de lo que es cruzada y, por lo tanto, se puede decir que hablan en términos científicos más propiamente.

Pero antes de ello, el debate ha continuado sobre la pervivencia o no de un ideal de reconquista a lo largo de toda la edad media, divagar si se puede usar el término reconquista, o cuándo se produce la introducción del elemento de restauración visigoda, o el de guerra santa, etc. S. Albornoz y A. Castro, y sus respectivos discípulos, han discutido largo tiempo sobre la importancia del medievo en la conformación de la nación española y los españoles. Sin embargo sus posturas no son tan enfrentadas como pudiera parecer, sino que son más bien dos formas de ver un mismo fenómeno desde perspectivas diferentes. Ambos están de acuerdo en que la lucha contra los musulmanes es un elemento fundamental conformador de los españoles. Dejando a un lado la pervivencia o no de un determinado «ideal de reconquista", ambos autores coinciden en que en la península se esta produciendo una guerra religiosa. Mientras que Albornoz prefiere destacar el carácter autóctono de la lucha y la importancia de ésta para el resto de Europa ${ }^{123}$, Castro prefiere resaltar la tolerancia, el contacto, y que tanto la guerra santa como la tolerancia son respuestas imitativas a un anterior modelo islámico (de ahí que también diga que las Órdenes Militares nacieron a imitación de los ribat musulmanes ${ }^{124}$ ). Sea cual fuera el origen o modelo de esta guerra santa, guerra lucha en nombre de la religión o por un determinado Dios, el caso es que ésta es un elemento fundamental del medievo hispano. J.A. Maravall aportará una visión más europeísta del fenómeno, intentando integrar lo que ocurre en la península con el resto de Europa, siguiendo las directrices básicas de Menéndez

123 «Como la guerra contra los almorávides, almohades y benimerines, y con el reino moro de Granada, suscitaba fervores de lucha nacional y religiosa, el dinamismo del guerrero se dobló en el castellano del entusismo religioso del cruzado, según atestiguan mil sucesos y, entre otros, los repetidos y generosos subsidios votados por las cortes de Castilla...", SÁNCHEz Albornoz, España y el Islam, Buenos Aires, 1943, pp. 41-42. Kernaghan cita otro texo de Albornoz: «La Reconquista no fue ni guerra santa ni cruzada, como la entendió la cristiandad occidental durante los siglos XI al XiII. Porque no se llevó a cabo con fines religiosos ni se buscó la extensión de un credo religiosos por la espada". Desconocemos de dónde procede esta cita (Kennaghan, P., Las Cruzadas: culturas en conflicto. Adaptaciçon española, C. Cortés Salinas, et alii, Torrejon de Ardoz, 1994. [selecc. de la versión inglesa, de Cambridge, 1993], pp. 78-79).

124 AMÉRICO CASTRo, Los Españoles, Cómo llegaron a serlo. Madrid, 1965; ídem, Españoles al margen, Madrid, 1973, p. 33. «En las cimas de la cultura española, durante los siglos XII-XIV, se daba a la guerra, ya multisecular, un sentido paralelo al de los musulmanes" (ídem, Aspectos del vivir hispánico... siglos XIV-XV. Santiago de Chile, "Cruz del Sur», 1949. Cit. ANTELo IGLESIAS, A., «El ideal de Cruzada en la Baja Edad Media peninsular». Cuadernos de Historia, I (1967): 37-43 (Madrid, 1968), p. 39.) 
Pidal sobre continuidad de un ideal de reconquista, aunque matizando mucho el aspecto religioso ${ }^{125}$.

Por otra parte, y a modo de inciso, la aparición del libro de Erdman sobre la Reconquista en Portugal y su libro general de la cruzada ${ }^{126}$ que defendía que lo que había sucedido en la península antes de la influencia cluniacense del siglo XII no tenía nada que ver con una guerra santa (y por ende con la cruzada, dada la casi nula diferenciación que hace entre una y otra), recogió inmediata contestación a un lado y otro de la frontera portuguesa defendiendo la reconquista desde el principio como guerra santa y su total identificación con la cruzada ${ }^{127}$.

A mediados de la década de los cincuenta, en paralelo a la importante producción historiográfica que se está produciendo fuera de nuestras fronteras nos encontramos con los trabajos ya citados de Benito Ruano y la fundamental obra de G. Gaztambide ${ }^{128}$. Merece la pena detenernos un poco en estos autores ya que son los primeros que se dedican a diferenciar lo que es guerra santa de cruzada, y sacar a partir de ello sus conclusiones sobre la península.

Benito Ruano va estudiar el tema de las cruzadas y la Reconquista a través, básicamente, de sus estudios de las O. Militares hispanas. Ya en 1952 dedica un artículo a «España y las cruzadas» y un par de años más tarde participará en el congreso de ciencias históricas que se desarrolló en Italia y que tenían como objeto las cruzadas. Pues bien, desde el principio queda clara su postura. Las cruzadas que tienen un definidor carácter religioso y que se enmarcan dentro de la confrontación entre oriente y occi-

125 Maravall, J.A., «La idea de Reconquista en la España Medieval», Arbor, XXVIII (1954): 137; idem, El Concepto de España en la Edad Media. Madrid, 1981.

126 Erdman, C. A., Idea de Cruzada em Portugal. Coimbra: Instituto Alemao, 1940 (basado en «Der Kreuzzugsgegeclanke in Portugal» en Historisches Zeitschrift, 141 (1930, pp. 23-53). Criticado en la Revista Portuguesa de Historia, 1 (1941, 305-311) \& t. XI, 1962 (1-54). Idem, The Origin of the ldea of the Crusade, Baldwin; Goffart; Marshall ed. Princeton: 1977 (del original Alemán: Die Entstehung des Kreuzzugsggedanken, Stuttgart, 1935).

ik7 SOuzA SOARES, T.D., «Crítica a la idea de Cruzada en Portugal, de C. Erdman». Revista Portuguesa de Historia, 1 (1941): 305-11. R. Menéndez PIDAL, La España del Cid, Madrid, 1947, 4. ed. pp. 66-68. VHLlosladA, dir., Historia de la Iglesia de España, t. II, Madrid: ed. 1982, pp. 358-396. Goñı GaztAmbide, J., Historia de la Bula de ia Cruzada en España. Vitoria: 1958, pp.15-42.

128 Benito Ruano, E., «Balduino II de Constantinopla y la Órden de Santiago. Un proyecto de defensa del Imperio Latino de Oriente." Hispania, 12 (1952): 3-36; ídem, "España y las cruzadas". Anales de Historia Antigua y Medieval (1951-1952): 92-120; ídem, Huéspedes del Imperio de oriente en la Corte de Alfonso $X$ el sabio. Tirada aparte de Estudios Dedicados a Menéndez Pidal, Madrid, 1956; idem, "Las Órdenes Militares españolas y la idea de Cruzada». Hispania, 16 (1956): 3-15; ídem, "La Iglesia Española ante la caída del Imperio Latino de Constantinopla» Hispania Sacra,Xl (1958): 3-20. Goñ GazTAMBIDE, J., Historia de la Bula de la Cruzada en España. Vitoria: 1958. 
dente fueron motivadas en su origen por 4 causas: la penuria y carestía en Europa, la atracción económica de Oriente, el carácter imán de Tierra Santa (por las crecientes peregrinaciones) y el clima de beligerancia que se respira principalmente por el Islam. El movimiento cruzado se justifica y define por: ideal religioso (místico-transcendente), la nueva caballería como motor épico-militar, la universalidad del movimiento y el romanticismo-aventurismo de la época. Basándose sobre la producción científica de la segunda mitad de los años cuarenta, Ruano va perfilando su postura. Aparte de otros motivos y contexto socio-político-cultural, en su origen y desarrollo. Se acude a la llamada de la cruzada, fundamentalmente, por razones ideales y espirituales (Michaud), siendo un tipo especial de guerra santa "peregrinación guerrera» ${ }^{129} \mathrm{y}$ dentro del contexto del mundo cristiano medieval como oposición al mundo islámico. Aunque luego se desvirtuara ${ }^{130}$, al principio fue un movimiento universal y unificador de la cristiandad occidental, animado por las indulgencias y dirigido por los papas como jefe supremo. De ello no se puede excluir ni a España ni la expansión hacia el este de los países alemanes. De hecho la reconquista, entendida como una necesidad vital, y aparte de las características peculiares dentro de la confrontación entre oriente y occidente, «... es ante todo guerra antiislámica, y la guerra religiosa predominaba en el fondo o abiertamente sobre cualquier otra razón... ${ }^{131}$ ", «... recuperación del territorio sagrado y consagración de la lucha en sí»; lo cual lo identifica en parte o en todo con las cruzadas. La guerra en España fue la precursora e integrante del movimiento cruzado. Los papas ya se habían venido fijando en la lucha peninsular desde inicios del siglo XI y define la campaña de Barbastro (1063) como la primera cruzada, aunque no jurídicamente (ya que no está claro el tema de la indulgencia o la iniciativa papal), sí espiritualmente. Se muestra en desacuerdo con Boissonade y de acuerdo con Defourneaux sobre la importancia de la presencia de caballeros franceses en la guerra peninsular, que considera como muy limitada y en ningún

129 ROUSSET, Les origins et les caracteres de la premiére croisade. Ginebra, 1945.

130 Habla otra vez del fin de las cruzadas desde mediados del siglo xII! y especialmente desde 1270. Postura esta del declive de la cruzada a mediados del siglo XIII que casi se «institucionalizós a partir de las comunicaciones presentadas por Villey y Runciman en el Congreso internacional de ciencias históricas de 1952. (VILLEY, M., «L'idee de Croisade chez les juristes du moyen age», Relazioni del X congresso Internazionale di Science Storiche, v. III. Medioevo. ed. G.C. Sansoni. Firenze, 1955, pp. 565-594; y RuncimaN, S., "The declining of the crusading idea", Relazioni del $X$ congresso Internazionale di Science Storiche, v. III. Medioevo. ed. G.C. Sansoni. Firenze, 1955. pp. 637-652).

131 BENITO RUANO, E., «España y las cruzadas», Anales de Historia antigua y medieval (195152): $92-120$, pp. 100-101. 
caso definitoria, destacando la importancia de la influencia papal y la de Cluny e incluso el de las relaciones dinásticas como atrayentes y conformadores del apoyo europeo a la guerra santa en la Península. En definitiva, en España se encuentra el origen de las cruzadas, el modelo hispano (el de Barbastro y Tarragona, 1073) sería el que fuera seguido por las cruzadas orientales, más atrayentes que las peninsulares. A pesar de ello los papas se habrian preocupado desde el principio en identificar a los guerreros peninsulares con los cruzados a Tierra Santa (igualdad de indulgencias) y de mantener a los caballeros hispanos dentro de la península para guerrear contra los musulmanes de casa (poniendo como modelos de cruzadas peninsulares la de Zaragoza, 1118 y la de las Navas de Tolosa, 1212) ${ }^{132}$.

Gaztambide, en 1958, empieza por definir la reconquista como guerra santa en oposición a la interpretación laica que bastantes autores (básicamente extrapeninsulares: Erdmann, Brackmann, Kienast, Gieysztor, van Prag, Villey hasta finales del XI... aunque también incluía a Menendez Pelayo, Ibarra y Maravall) daban a la reconquista. A ella le opone la concepción tradicional defendida entre otros por Menéndez Pidal y Sánchez Albornoz. Define lo que es guerra santa: " como guerra santa se entiende toda guerra emprendida por motivos religiosos... Defensiva u ofensiva, la guerra contra los enemigos de la fe tenía un carácter meritorio, era considerada como una obra santa, un deber religioso, un servicio a la cristiandad. Los fieles estaban convencidos de que combatian por Dios y su Iglesia, defendían o extendían la Cristiandad, aumentaban el culto divino y ensalzaban la fe Católica» ${ }^{133}$. Por supuesto Goñi va a defender que desde el principio de la reconquista los autores cristianos tenían una clara conciencia de que la lucha que estaban llevando a cabo contra los musulmanes era una guerra santa, una guerra de liberación y defensa de la iglesia, de una guerra misionera que extiende el reino de Dios no por la persuasión sino por las armas con un marcado carácter de restauración. Si en sus fines y móviles la reconquista es una guerra santa, también lo era en su técnica, en su estrategia espiritual. Entre esa estrategia está la importancia de la protección de los santos y lo que se va a convertir en un elemento característico: la peregrinación compostelana como símbolo de esa

13230 años más tarde dirá:» (la cruzada) es el ápice ideológico y fáctico del sentimiento medieval de contraposición al Islam. Es desde luego, un hecho bélico... pero es, tamién, y sobre todo, un movimiento ideológico...", BEnIto RuAno, E., De la alteridad en la historia, Madrid, 1988, p. 59.

i33 Goñ Gaztambide, J., Historia de la bula de la cruzada en España. Vitoria, 1958. 
protección. Defiende la relación entre peregrinación y guerra santa aunque sean cosas diferentes. Así mismo va a destacar la persistencia de ciertos elementos en la guerra peninsular como la bendición del ejército por la iglesia; la cruz como divisa de los combatientes, y la presencia de la iglesia en la guerra. Todo ello le conduce a negar la interpretación laica, incompatible con el espíritu de la época. A vista de todo lo cual identifica plenamente la cruzada con la reconquista, siendo fundamental los motivos religiosos. Aunque reconoce otros motivos políticos, territoriales y económicos, éstos no pueden hacer sombra al elemento caracterizador religioso ${ }^{134}$. Ahora bien, el siglo XI presenta una nueva fase de la reconquista marcada por su carácter ofensivo y que se enmarca dentro de una expansión general de la cristiandad. Aparecen nuevas fuerzas en el escenario peninsular como la simpatía de Cluny, el aliento del Papa a las empresas peninsulares y la presencia de caballeros franceses en la lucha antiislámica, marcados por la perspectiva del botín. Pero, ¿qué es cruzada? Después de dar un repaso a las principales posturas historiográficas opina que la cruzada es un tipo específico de guerra santa, no es una igualdad. Después de hablar de las versiones exclusivistas de Grousset o legalistas de Villey y Rousset, Gaztambide se va a decantar por una definición más flexible de la misma: "la cruzada es una guerra santa indulgenciada» ${ }^{135}$. Dichos elementos conformizadores se van a encontrar en Barbastro (1063) y, por lo tanto, dicha expedición realiza la primera forma de cruzada. A la hora de estudiar los elementos que pudieron llevar o influir en el carácter de la guerra santa peninsular y su transformación en cruzada, Gaztambide va a desestimar la influencia de Cluny y la presencia de los franceses, otorgando una mayor importancia a la preocupación con la que los papas venían siguiendo el conflicto en la península desde principios del siglo XI, desembocando en los episodios de Barbastro (19063) y. Tarragona (1089), que dan lugar a la identificación plena entre cruzada y reconquista en la primera cruzada (1095) por Urbano II, confirmada en el concilio de $1123^{136}$.

La Historia de la Iglesia de Villoslada de 1953 y la edición del BAC de $1982{ }^{137}$ vuelven a poner el énfasis en el aspecto y motivaciones religiosas del movimiento, rechazando la interpretación laica de la reconquista como

134 Goñl Gaztambide, J., Historia de la bula de la cruzada en España. Vitoria, 1958, cap. II, p. 17-42.

135 Goñl Gaztambide, J., Historia de la bula de la cruzada en España. Vitoria, 1958, p. 46.

136 Goñl GazTAMBide, J., Historia de la bula de la cruzada en España. Vitoria, 1958, cap. III, pp. 43-62.

${ }_{137}$ García VILloslada, dir., Historia de la lglesia de España, t. II, Madrid, 1982 (original de 1953). 
opuesta al espíritu religioso de la época. Se vuelve a afirmar la tesis de la continuidad, desde un principio, del un ideal de reconquista alimentado por un ideal religioso que toma su continuo batallar «como una cruzada o guerra santa en pro de la religión de Cristo». Esta idea de cruzada es la generadora de España... «los españoles mantienen siglos enteros de lucha por la fe cristiana más que por la patria, pero lucha con el fanatismo cruel de otras razas». Villoslada al igual que hiciera Souza de Soares para el caso portugués y lo volvería hacer $\mathrm{G}$. Gaztambide en su libro, dice: «creemos que yerra Erdman (p.89-91) al negar el carácter de guerra santa (que él identifica con cruzada) a la reconquista peninsular antes de la influencia cluniacense...» ${ }^{138}$. La edición de 1982 aprecia claramente la distinción entre guerra santa y cruzada. Por ello, «la cruzada se debe reservar para aquella guerra santa predicada y en cierto modo dirigida por el papa en cuanto cabeza y jefe de toda la cristiandad", incluye un carácter supranacional y universal y, normalmente, se conceden indulgencias plenarias de los pecados. Destaca la utilización de la cruz que el propio pontífice entregaría a un legado o representante suyo pero que no dirigiría el combate («Vexilum crucis o vexilum sancti petri», aunque ésto no sea una condición esencial) ${ }^{139}$. Se hace eco sobre la división de opiniones que han provocado las campañas de 1066, 1087, 1063 (Sicilia) en la conformación del ideal cruzado; y aunque hace lo mismo sobre Barbastro, al final tiende a apoyar la opinión de autores como Boissonade, Menéndez Pidal, Erdman o Mansilla que sí la consideran como la primera cruzada (en contra de la opinión de otros como Villey).

En la década de los sesenta los trabajos de Antelo Iglesias y Dias Dinis coinciden en destacar la importancia de la guerra en la Península, primero guerra santa y luego cruzada, en la pervivencia de un ideal cruzado desde los siglos XIII al XVI y su traslado a la conquista de América ${ }^{140}$.

En 1966, García de Cortazar, en un libro enfocado a la juventud que se preparaba el acceso a la Universidad, va a mostrar muchas de las ideas que Riu y Riu también afirmaría 3 años después ${ }^{141}$. Primero establece el escena-

138 García Villoslada, dir., Historia de la Iglesia de España, t. II, Madrid, 1982, cap. III, pp. 358-396.

139 Gafcia Villoslada, dir., Historia de la Iglesia de España, t. Il, Madrid: 1982, p. 364.

140 ANTElo lglesias, A., "El ideal de Cruzada en la Baja Edad Media peninsular». Cuadernos de Historia, I (1967): 37-43, que cita aprobatoriamente a L. Von Ranque en el mismo sentido. Días Dínis, A. J., "Antecedentes da Expansao Ultramarina Portuguesa. Os diplomas pontificios dos séculos XII a XV». Revista Portuguesa de Historia, X (1962): 1-118.

141 García de Cortazar y Ruiz. de Aguirre, J.A., Las cruzadas. Bilbao, 1966. Definción en la página 27. 
rio del nacimiento de la cruzada: una Europa occidental cristiana donde destaca la presión que el ingente aumento de la población realiza sobre las fronteras de los paganos y el auge del comercio. Ese contexto es general y será causa común a los 3 fenómenos expansivos: reconquista, cruzada y marcha hacia el este. Sin embargo destaca el ideal religioso de las gentes, aunque entre los motivos para ir a las fronteras también se incluyan el ansia de botín o la adquisición de nuevas tierras para asentarse. Al mismo tiempo tenemos una clase guerrera revalorizada al afirmar el papa que a través de la lucha también se puede conseguir la salvación. Sin embargo la chispa de todo este proceso se produjo en España y cita la campaña de Barbastro (en represalia a la muerte de Ramiro I) como la $1 .{ }^{\text {a }}$ verdadera cruzada ya que «la predica un papa, la escuchan unos caballeros, la dirige la fe contra los infieles y compensa sus sufrimientos las indulgencias. A partir de aquí no habrá novedad en el movimiento cruzado: únicamente cambiará el escenario". Es decir que las cruzadas nacen en España, siendo Barbastro donde se creó un ambiente de cruzada que posteriormente sería explotada en 1095 por el papa. Fecha a partir de la cual, debido a la mayor popularidad de Tierra Santa (gracias en parte las peregrinaciones), la cruzada se dirigirá a Tierra Santa. Al final, y de acorde con su época, vuelve a reivindicar el espíritu religioso de las mismas, no sin reconocer que los cruzados también podrían estar animados por la expectativa de ganancias terrenales. Finalmente, vuelve a confirmar la teoría general de la época acerca de que el espíritu de cruzada muere en el siglo XIII, de hecho ya casi desde el final de la III cruzada, siendo las campañas de S. Luis del siglo xIII una excepción. Veinte años más tarde, García de Cortazar, ha matizado mucho su posición sobre la religión haciendo también mención a la problemática Reconquista/cruzada. Por supuesto enmarca lo que sucede en la península con el movimiento general de expansión europea y los fenómenos socioeconómicos que la sacuden. Dice que se pasa de una actitud defensiva de la comunidad cristiana, hasta el siglo XI, a una ofensiva (dentro del contexto de la cristiandad latina). "La Reconquista, como ocupación violenta de tierras habitadas por los musulmanes, es un fenómeno que va desde mediados del siglo XI a mediados del siglo XIII (1260), guardando un estrecho paralelismo con la Drang Nach Osten y las cruzadas. En los 3 casos, la ocupación de los territorios enemigos se hace, alternativamente, a través de una colonización pacífica y unos enfrentamiento bélicos, a los que el naciente ideal de cruzada, producto de una Iglesia reestructurada y combativa, proporciona una justificación de combate por la fe» ${ }^{142}$. Junto a este criterio ideo-

142 García de Cortazar, J.A., Historia de España II, Dir. por M. Artola. Ed., pp. 135. Rev., Madrid, 1988. Orig., 1973. Idem, «Un tiempo de cruzada y guerra santa a finales del s. XI». LOS monjes soldados. Palencia, 1997, pp. 9-31. 
lógico, la reconquista parece apoyarse más en el de recuperación de un territorio para restaurar en él un dominio político legítimo, el heredado de los reyes Godos; sentimiento en el que tanto Cataluña como Castilla participan mucho más tardíamente y siempre como algo secundario».

Así mismo Riu Riu lleva casi hasta el límite las ideas de G. Gaztambide sobre las cruzadas y los reinos peninsulares. Empieza hablando del contexto internacional de la $1 .^{a}$ cruzada, la revolución comercial de los siglos XI y XII, del aumento demográfico y de la situación del imperio bizantino. Acto seguido pasa a decir que: «para la cristiandad occidental de los siglos XII y XIII las cruzadas fueron guerras santas o peregrinaciones armadas, dirigidas por la Providencia divina através del papa, con objeto de abatir el islamismo y librar la Tierra Santa (Palestina) de la dominación musulmán. Fueron guerras caballerescas, emprendidas con ánimo esforzado y alto sentido del honor...". Prima como elementos conformadores de la $1 .^{a}$ cruzada los factores religiosos y caballerescos. Riu Riu llega a afirma que "mucho antes de que el occidente europeo se lanzara a la empresa de las cruzadas, las habían, de hecho, iniciado Bizancio y España para recuperar sus respectivos territorios. Pero con los siglos el carácter y espíritu de cruzadas fue transformándose... (a peor...)". Así mismo confirma la idea de que la cruzada pudo haberse originado en España y habla de, al menos, tres empresas cruzadas, precedidas por sus correspondientes bulas de cruzada. Éstas serian las de Barbastro (1063-1064) promulgada por Alejandro II; la segunda "cruzada» de Eble de Roucy a tierras del Ebro en 1073, apoyada por Gregorio VII; y siendo la tercera la favorecida por la bula de Urbano II para la toma de Huesca, precedida por la conquista de Alfonso VI de Toledo con ayuda de cruzados franceses. En definitiva, Riu habla de una desviación de la cruzada de la Península hacia Oriente: «El escaso éxito de las cruzadas occidentales y la política de aproximación al oriente bizantino,... la unión de las iglesias... y la petición de ayuda..., desviaron hacia el este la lucha contra los infieles, alentando el espíritu de cruzada entre los caballeros de Europa occidental»" ${ }^{143}$.

Por su parte Vicens Vives, admirador de S. Albornoz, parece que dijo «Al filo del siglo XII surge el ideal de reconquista como eliminación violenta de los musulmanes de las tierras de España, tanto por su calidad de "usurpadores" de lo visigodo como - y este hecho es esencial- de adversarios de la fe católica»... «siglo XII guerra contra los musulmanes por

143 Todas las citas, Riu Riu, M., Lecciones de Historia Medieval. Barcelona, 1985, pp. 300302, 306-7, reed. de la obra de 1969 . 
ideal, tierra y religión» ${ }^{144} \operatorname{Sin}$ entrar en mayores detalles de identificación entre cruzada y Reconquista...

En 1972 aparece la pequeña obra de Ladero Quesada que supone un paso adelante más ${ }^{145}$. En su obra destaca la importancia de la influencia de la intransigencia almorávide en la conformación de una mentalidad de hostilidad nata/religiosa por parte de los reinos cristianos peninsulares. Por supuesto enmarca el nacimiento de las cruzadas dentro de un contexto general europeo de aumento de las monarquías y de conformación del sistema feudal junto al aumento demográfico y el auge del comercio favorecido por la reconquista de las rutas mediterráneas. (s. XI). Para él, las causas se agrupan en dos grupos. Por un lado las motivadas por el contexto socioeconómico. Por otro, destaca la motivación religiosa-espiritual, especialmente representada en el elemento de la peregrinación. Todo ello también dentro de la polémica del enfrentamiento entre papado e Imperio por el liderazgo de la cristiandad. Así, se opone a las teorías que intentaban explicar a las cruzadas como un episodio más del enfrentamiento entre Oriente y Occidente (defendida entre otros por Atiya) o el de la teoría colonial (representada por Grousset). Al final destaca la importancia de la mentalidad en la configuración de este tipo de guerra santa, apuntando en esta dirección la importancia de la promesa del perdón de los pecados, la popularidad de la peregrinación y la creciente figura papal. Señala el ataque a Mahdia en 1088 como fruto de un proyecto papal que se podría asemejar a la cruzada y cita la campaña de Alfonso I de Aragón contra Zaragoza en el siglo XII como de verdadera cruzada.

Pierre Villar, en la década de los setenta, también llega a identificar reconquista (al menos gran parte de ella) con cruzada. Habla de una cruzada que ha durado varios siglos, aunque los jefes no siempre tuvieran una clara conciencia de los fines perseguidos, y dice: "Pero la presión de las necesidades en un país pobre y de población creciente, hizo en todas partes de la Reconquista una empresa de colonización permanente, a la vez que una guerra santa» ${ }^{146}$, volviendo al querido tema francés de cruzada como colonización.

Al final de esa misma década, y ya dentro de una nueva corriente de pensamiento historiográfico, las obras de Barbero y Vigil o José Luis

144 Cit. Kernaghan, P., Las Cruzadas: culturas en conflicto. Adaptaciçon española, C. Cortés Salinas, et alii, Torrejon de ardoz, 1994 (selecc. de la versión inglesa, de Cambridge, 1993).

145 Ladero Quesada, M.A., Las Cruzadas. Bilbao, 1972.

146 Cit. Kernaghan, P., Las Cruzadas: culturas en conflicto. Adaptación española, C. Cortés Salinas, et alii, Torrejon de Ardoz, 1994 (selecc. de la versión inglesa, Cambridge, 1993). 
Martín recogen parte de la teorías de $\mathrm{M}$. Pelayo al argüir que no se puede hablar de una continuidad de la reconquista desde la invasión musulmana hasta los reyes católicos, siendo los mozárabes emigrantes los verdaderos autores del «ideal» de reconquista ya a fines del siglo IX, intentado amalgamar las teorías de la unificación del antiguo reino godo con la defensa de la cristiandad ${ }^{147}$.

Lomax, que defiende la percepción del fenómeno de la reconquista dentro así mismo del mayor movimiento cruzado, también entiende que sólo se puede hablar de un elemento caracterizador religioso desde la venida del elemento mozárabe a los reinos cristianos del norte a mediados del siglo IX, como se plasma en las crónicas de la época ${ }^{148}$.

V. Cantarino, en 1978, se va a oponer a Villoslada en cuanto al carácter religioso de la reconquista desde los primeros tiempos; y a Bishko en cuento al principal elemento de influencia en la conformación del nuevo carácter de la guerra. Cantarino niega que se pueda hablar de una guerra santa desde el principio de la Reconquista, como hablaba Villoslada. De hecho, en principio, sólo había interés por recuperar tierras a lo que se unió un sentimiento de recuperación goda, introducido por los mozárabes a mediados del siglo Ix, lo cual daba lugar a una "guerra justa», y no una guerra santa. Afirma también que «no es compatible la noción de cruzada con síntomas de contacto». En la conformación del nuevo carácter guerrero a lo largo del siglo XI y que tendría sus verdaderos frutos en el siglo XII destaca la importancia de Cluny sobre todas las cosas, tanto por su relación el papado como con el camino de Santiago, siendo éste último camino de propagación de un ideal bélico que tendría a Carlomagno como figura cruzada modelo. "La cruzada, o mejor dicho intransigencia española, sería por contraste a la del enemigo» y habla de una "reelaboración del concepto de reconquista» visible en los siglos XII y XIII aunque el papa ya reconociera la importancia del escenario peninsular igualándolo al Oriental desde la I cruzada de 1095. En fin, se sigue confirmando en que la causa principal de la reconquista no fue la crhistianitas, sino la lucha por la riqueza territorial ${ }^{149}$.

Dos años más tarde, Bishko hablará de tres movimientos de cambio histórico que afectarán al origen de la cruzada: La expansión interna de los reino cristiano, el nuevo conflicto con las dinastías norteafricanas y la vi-

147 Barbero, A., y Vigil, M., La formación de del feudalismo en la Península lbérica. Barcelona, 1978.

148 LOMAX, D.W., The Reconquest of Spain. Londres, 1978.

149 Cantarino, V., Entre monjes y musulmanes, el conflicto que fue España. Madrid, 1978. 
sión de la España reconquistada como paso a Jerusalén. Ahora bien el carácter de cruzada será otorgado a la guerra peninsular sólo después de Clermont (1095), y ese nuevo carácter magnificará los objetivos religiosos del movimiento peninsular y su influencia, a la vez que atraerá a cruzados de fuera de la península. No considerará que la intervención de Cluny fuera decisiva en esta conversión de la Reconquista en una cruzada ibérica; sino más bien el papado, con sus bulas de indulgencias, como las actas del I concilio de Letrán (1123) que equiparaba la lucha en suelo peninsular con el de Tierra Santa ${ }^{150}$.

J.L. Martín, como la mayor parte de los medievalistas españoles, vuelve sobre el tema de los orígenes de la reconquista. Afirma que al inicio (s. VIII) sólo se puede hablar de resistencia, que no tiene nada que ver con las ideas de unidad y defensa del cristianismo que serán introducidas mucho más tarde, estando ligado el verdadero perfil de la reconquista a la recuperación de antiguos territorios visigodos, a partir de mediado del siglo IX por influencia de la inmigración mozárabe. Va a definir a las cruzadas, fruto de las ideas teocráticas de los siglos XI-XII como "expediciones guerreras dirigidas por el papa o por sus representantes, al que se someten cuantos intervienen en la expedición; en principio la cruzada se dirige contra Jerusalén y tiene como objetivo la liberación de los Santos Lugares, aunque los segundones también tuvieran un móvil económico. La cruzada se va convirtiendo, sin perder su carácter inicial, en el modo de combatir del pontífice a los que se le oponen dentro del mundo occidental; el factor religioso ha dado paso a la orientación eclesiástica y se dará el nombre de cruzada a cualquier guerra dirigida y apoyada por Roma contra infieles y herejes, dentro de los cuales se incluye a los excomulgados, bien por razones políticas y/o religiosas". A partir de la segunda mitad siglo $X I$ se produce un importante cambio que tiene mucho que ver con las relaciones exteriores de los poderes peninsulares con la Europa cristiana y el norte de África musulmán respectivamente. Con respecto a la península «como reacción frente a la intransigencia (Amorávide), se endurece la postura de los reinos cristianos, que aceptarán y pedirán la ayuda de cruzados europeos... y reactiva el espíritu cruzado entre los cristianos». (Ej. de Alfonso el Batallador, Zaragoza, 1118) ${ }^{15 t}$. Ocho años más tare J. L. Martín publicará un libro de divulgación sobre las cruzadas defi-

150 BıSHKO, C. J., "The Spanish and Portuguese Reconquest, 1095-1492.» Studies in Medieval Spanish Frontier History, Londres, 1980, p. 399.

151 Martín Rodriguez, J.L., «Una Sociedad en guerra. Reinos Cristianos y Musulmanes, siglos XI-XIII.» Historia de España 16, Madrid, 1980, tomos III-IV. 
niéndolas como guerras santas dirigidas por el pontífice, teóricamente, que en el momento de la partida concede privilegios espirituales y temporales a los participantes...", siendo una manifestación de la religiosidad medieval y del poder alcanzado por los pontífices a los que prontamente se les escaparía el control. La respuesta de occidente vendría marcada tanto por móviles religiosos y económicos como políticos. También se hace eco del contexto europeo de la época: Cluny y la reforma de la Iglesia, el creciente poder del papado - figura que considera crucial-, el intento de conseguir una paz interior cristiana, el ansia de búsqueda de nuevas tierras y riquezas, los problemas oriente-occidente, la petición de ayuda de Bizancio y los intereses comerciales de las ciudades italianas junto a la nueva piedad popular unida a la importancia creciente de la peregrinación («la cruzada es una peregrinación armada» ${ }^{152}$ ). Dice que por contraste a una cruzada popular ${ }^{153}$, se fue prefiriendo una "cruzada eclesiástica, no religiosa, al servicio de la iglesia, y profesional o cruzada de los caballeros que ponen al servicio de un ideal cristiano su habilidad guerrera» y lo enlaza con la desviación de la cruzada desde Inocencio III, a fines del siglo XII. Final y más recientemente, este autor no está convencido de que a Barbastro se la pueda considerar como tal cruzada, como tampoco considera que los hispanos del siglo XI tuvieran algo que ver con el «espíritu cruzado». Coincide así con Erdman en cuanto a que los intereses hispanos estaban centrados en las parias y en las tierras más que en cualquier otra motivación religiosa y, por ende, cruzada ${ }^{154}$.

El historiador portugués, Mattoso, apoya la interpretación laica de la reconquista y la cruzada. Para él sí existe una diferencia entre las guerras contra los musulmanes que tenían un sentido verdaderamente militar y político, por oposición a las guerras entre los reinos cristianos que considera guerras de tipo señorial en la que se disputan un montón de derechos subjetivos. Las guerras contra los musulmanes, dirigidas por el poder real, tienen como único fin la ganancia de poder político y territorios. En cuanto a la importancia de los motivos políticos de la reconquista se muestra de acuerdo con M. Pelayo y otros, aunque disiente finalmente de éste

152 Martín Rodríguez, J.L., Las Cruzadas, Cuadernos de Historia 16, 140, 1985.

153 Sobre el debate en torno a la importancia del elemento «popular» en el origen y conformación de las cruzadas ver: CARDINI, F., «Per una ricerca sulle crociate populri», Cuaderni medievali, 30 (1990): 156-167; HousLEy, N., "Jerusalem and the Development of the Crusade Idea, 1099-1128», 27-40. The horns of Hattin. ed. B.Z. Kedar, Jerusalem, 1992. («1987 conf., que se opone a Keen); TYERMAN, C.J., "Were there any Crusades in the 12th century?», English Historical Review, 110 (1995): 553-577; y RILEY-SMITH, J., The first crusaders. Cambridge: 1997.

154 Martín Rodriguez, J.L., "Reconquista y Cruzada» Studia Zamorensia, VIII (1996): 215-241. 
cuando Pelayo, al final, reconocía una equiparación entre cruzada y reconquista. Mattoso, en definitiva, se mostrará de acuerdo con Erdmann al negar el carácter religioso o santo de la guerra en la península ibérica ${ }^{155}$.

Otro moderno hispanista $\mathrm{R}$. Fletcher también niega el carácter religioso de la guerra en la península ibérica. Mientras que otros autores hablaban de la posibilidad de influencias internas o externas a la península que la irían dotando de una serie de elementos que conformarían un carácter de guerra santa y/o cruzada, Fletcher afirma que no existieron tales elementos; sino que el ideal religioso de la guerra, y en definitiva la cruzada tuvo que ser «implantado» en la península por parte de elementos foráneos hacia el segundo cuarto del siglo XII. Por supuesto ataca con dureza el ideal del caballero presentado por Menéndez Pidal en su retrato del Cid y niega cualquier posible influencia de lo que sucedía en la península ibérica a la hora de la conformación de la ideología cruzada ${ }^{156}$.

Mientras tanto, el profesor González Jiménez, gran conocedor de la época de Alfonso $X$, ha venido sosteniendo que sí hubo una permanente idea de «Reconquista» reforzada, desde la caída de Toledo, por la idea de cruzada ${ }^{157}$.

El profesor JM. Mínguez se ha venido oponiendo a la visión de la Reconquista de Lomax y a la visión tradicional que consideraba a la reconquista (722-1264) como un movimiento político-religioso destinado a la restauración de la antigua unidad político española del reino Visigodo. Para él la reconquista en un fenómeno económico-social de guerra y colonización ${ }^{158}$.

De las últimas aportaciones científicas al debate historiográfico dentro de nuestras fronteras sobre cruzada/reconquista, además de un par de trabajos generales sobre el fenómeno y los estudios de $\mathrm{C}$. de Ayala en torno a las Órdenes Militares, destaca el estudio de García-Guijarro de

155 Matroso, J., «A formaçao de portugal e a península iberica nos seculos XII e XIIl», Fragmentos da uma composiçao medieval. Lisboa: 1987, p. 65. Previamente, Oliveira ya se había hecho las mismas preguntas: ¿se puede identificar cruzada con reconquista? ¿reconquista es igual a guerra santa? Su respuesta era dudosa y, en cualquier caso, dependía según las épocas. (Oliveira Marqués, A.H., Historia de Portugal, pp. 88-89. Madrid, 1983. orig. 1972.)

156 Fletcher, R., The Quest for El Cid. Londres: 1988. Ídem,, «Reconquest and Crusade». Acts of the Royal Historical Society, 37 (1987): 31-47. Por otra parte, Lewis, en su estudio general sobre el enfrentamiento entre oriente y occidente, acepta la predisposición de España a la cruzada (plasmado en la campaña de 1073), pero dice que no se puede identificar esa "cruzada española» con la primera cruzada de 1099 (LEWIS, A.R., Nomads and crusaders, 1000-1368. Indiana: 1988).

157 GONZÁLEZ JIMÉNEZ, M., «Frontier and Settlement in the kingdom of Castile, 1085-1353». Medieval Frontier Societies, 49-74, Mackay, A., y Bartlett, R. Oxford: 1989. Cita aprobatoriamente a Lourie y Lomax (ver bibliografía).

158 Minguez, J. M., La Reconquista, Colección Historia 16, n. 18. Madrid, 1989. 
1993, centrado, también, en las Órdenes Militares. En definitiva, este autor vuelve a reclamar la importancia del elemento religioso como conformador del ideal de cruzada y elemento característico de él y destaca en el origen del pensamiento cruzado la reforma eclesiástica, la influencia de Cluny y la fundamental figura de los papas de la época. Estudioso de la evolución de la concepción de la guerra santa aboga por un desarrollo propio dentro de la tradición de la cristiandad occidental, en oposición a aquellos que buscan influencias o modelos en el mundo musulmán, bien sea de la propia guerra santa, bien sea de los ribat. Para este autor, el punto compartido relevante a todas las cruzadas es que «las expediciones eran manifestaciones de la pretendida preeminencia romana en el terreno espiritual y temporal. Sólo este núcleo dota de unidad a aspectos diversos, aunque no siempre trasciende a la formalización de diversas cruzadas» ${ }^{159}$. Así se pueden entender perfectamente las cruzadas a Tierra Santa, el Báltico o los intentos por someter a la iglesia griega $y$, en el mismo sentido, cuando afecta a hechos internos de la cristiandad occidental como las herejías o la oposición papado-Imperio. De esta manera se aleja de la postura legalista de Villey y, aunque defensor de la teoría de la heterogeneidad de frentes del fenómeno cruzado, no se muestra completamente de acuerdo con las características definitorias dadas por Riley-Smith o Housley. Las indulgencias no son un elemento definitorio y, por lo tanto, entre otras cosas, no tiene sentido hablar de unas determinadas "cruzadas políticas" (como se suelen llamar a las llevadas a cabo contra el Imperio), ya que todas ellas son políticas en tanto en cuanto dirigidas al mantenimiento de la preeminencia romana ${ }^{160}$. Sin embargo el autor muestra un clamoroso silencio en cuanto al tema de la reconquista o las luchas peninsulares en el origen, identificación y desarrollo de la ideología cruzada.

Damian y Smith destaca la significación de lo que ocurría en la península Ibérica en el desarrollo del fenómeno cruzado y, especialmente, la importancia, a su vez, del papado en la evolución de la Reconquista y su integración en la cruzada. Por su parte, la profesora Theresa Vann, en un ultimísimo trabajo, reafirmó la importancia de la lucha en la península en el origen de las cruzadas. Por supuesto, consideraba a Barbastro como la primera cruzada y no sólo se limitaba a citar los ya conocidos ejemplos de Barbastro y Tarragona para reafirmarse, sino que también abogaba por la

159 Garcia-GuiJarro Ramos, L., Papado, Cruzadas y Órdenes Militares, siglos XI-XIII. Madrid, 1995, pp. 243.

160 Garcia-Guijarro Ramos, L., Papado, Cruzadas y Órdenes Militares, siglos XI-XIII. Madrid, 1995, pp. 265. 
importancia del hecho de la conquista de Toledo, y todo el corpus diplomático adjunto, en la conformación del ideal y primeras reglas de las cruzadas ${ }^{161}$.

Ya hemos realizado un repaso a todas las posturas historiográficas peninsulares sobre la temática origen de la reconquista VS origen de la cruzada. Pero quedan aún otros factores, otros elementos, otras posturas, que nos permitan alcanzar una posicionamiento propio al respecto. Volvamos a hacer un repaso de los hechos.

Para empezar podemos comentar un caso evidente. Algunas personas que participaron y dirigieron en las primeras cruzadas tenían experiencia de primera mano sobre la guerra que se estaba llevando a cabo a este lado de los Pirineos, bien por experiencia personal, bien por la de allegados ${ }^{162}$. Es de suponer que de esta manera ya tenemos un primer punto de influencia de la guerra de la reconquista sobre el origen y desarrollo de la primera cruzada. Además, también puede ser lógico pensar que el papado, que había claramente mostrado su interés por el escenario peninsular, pudiera tomar ejemplo de lo que ocurría allí a la hora de pensar en la cruzada. De hecho hay ciertos autores que opinan que la experiencia, el modelo de la reconquista fue muy tomado en cuenta a la hora de decidir como sería la organización eclesiástica que los nuevos cruzados iban a crear en Tierra Santa sobre la marcha ${ }^{163}$. En general todos aquellos defensores de la heterogeneidad del fenómeno cruzado hablan de una cierta influencia, en menor o mayor medida, pero cierta, de la guerra peninsular contra los musulmanes en el origen de las cruzadas.

Otro medio de influencia pudo ser a través de Cluny. Muchos autores han comentado la influencia que esta orden pudo tener en la introducción o evolución del desarrollo de un ideal de guerra santa que desembocaría en cruzada en la Península y el resto de occidente. Lo cierto es que Cluny aprende todo y tiene como campo experimental a la península. Por lo tanto se podría pensar que todos aquellos que hablan de una influencia impor-

161 SMITH, D.J. "Soli Hispani"? Innocent III and las Navas de Tolosa», Hispania Sacra, 51 (1999): 487-513; VANN, T., "Reconquest and the origin of the Crusades», The Crusades: Other Experiences, Alternate Perspectives (Binghamton conference, 1999). En prensa. Acerca de otras últimas aportaciones ver $n .^{\circ} 177$, sobre Flori.

162 Por citar 2 obras que recogen a su vez varias opiniones al respecto, consultar: REYNAUD, G., «La lutte Chrétienne contre le pouvoir musulman en Occident ou L'Origine ibérique de la Croisade d'Orient", Sharq al-Andalus, 8 (1991): 243-247, y RILEY-SMiTH, H., The first Crusaders. Cambridge: 1997.

163 HiESTAND, R., «Reconquista, Kreuzzug und heiliges Grab: die Eroberung von Tortosa 1148 im Lichte eines neuen Zeugnisses», Gesammelte Aufsätze zur Kulturgeschichte Spaniens, XXXI (1984): 136-157, cit. por RILEY-SMITH, J., "Carl Erdman and the historiography of the crusades», Jornadas Internacionales sobre la I Cruzada, Madrid: 1998, pp. 17-29. 
tante de Cluny en la conformación del ideal cruzado implican una cierta influencia de lo que ocurría en el frente peninsular ${ }^{164}$.

En un reciente artículo de $\mathrm{N}$. Housley, éste comentaba que la "historiografía tradicional» consideraba que durante el periodo clásico de las cruzadas (1095-1291), las sociedades fronterizas, que en gran medida habían sido las propias objetos y destinatarias de esas ayudas cruzadas, no, o apenas, habían tomado parte en la génesis, evolución y desarrollo de la ideología, fenomenología e instituciones cruzadas; habiéndose desarrollado todas ellas en las cortes y universidades de Roma, y centro Europa ${ }^{165}$.

Aún ahora, el relativo papel que actualmente se le venía dando a España (ejemplo práctico) en la génesis de la cruzada está de nuevo siendo puesto en duda por M. Bull ${ }^{166}$, e incluso completamente negado ${ }^{167}$. Ello vendría a oponerse a posturas como las de Erdman, Mayer, Guiraud (1991), Riley-Smith, etc., que desde diferentes puntos de vista y por diferentes razones habían tomado el escenario peninsular y/o su guerra de reconquista como factores influyentes o a tener en cuenta a la hora de estudiar las cruzadas. Housley, en cualquier caso, dice que la importancia de esas sociedades fronterizas, especialmente la peninsular fue creciendo desde el siglo xIII y especialmente desde 1291. Otros autores que ya hemos visto como Antelo Iglesias también han reclamado esa importancia fundamental de pervivencia de un cierto ideal cruzado $\mathrm{er}_{\mathrm{i}}$ los reinos peninsulares y su influencia sobre el pensamiento general de la cruzada hasta bien entrado el siglo XVII. En el mismo sentido, la postura de M. Bull ya ha sido matizada, entre otros, por J. France ${ }^{168} \mathrm{y}$

164 Reynaud, G., «La lutte Chrétienne contre le pouvoir musulman en Occident ou L'Origine ibérique de la Croisade d'Orient", Sharq al-Andalus, 8 (1991): 243-247. Que cita aprobatoriamente a Delarueelle, Prawer (Prawer, J., Histoire du Royaune Latin de Jérusalem. París: 1969, p. 167) y CANARD [CANARD, M., «La guerre Sainte dans le monde Islamique et dans le monde Chrétien», Revue Africaine, 79 (1936):605-623].

165 Housley, N., «Frontier societies and Crusading in the Late Middle Ages», Mediterranean Historical Review, 10 (1995): 104-119.

166 BUL, M., Knightly piety and the lay response to the first crusade: the Lymosin and Gascony, 950-1130, Oxford, 1993, cap. 2.

167 FLETCHER, R., «Reconquest and Crusade in Spain, 1050-1150". Transactions of the royal Historical society, 37 (1987): 31-34.

168 Acerca de la opinión de Bull de que las guerras de España no habían tenido influencia sobre la actitud de los señores del norte (Bull, 21-69, 70-114), France piensa que sí tuvieron algo que ver en crear "cierto ambiente", que desde Carlomagno defendía la guerra contra los no-cristianos y que se estaba convirtiendo en odio contra los musulmanes. Hace referencia también a Ademar de Chabannes y sus citas de la guerra de Hispania, y comenta el problema del elemento peregrino. “... sin embargo, la historia del Cid debería guardarnos de considerar el conflicto en términos puramente ideológicos. Bien seguro que en España el Islam era el enemigo numero uno, pero no en cualquier momento fue el enemigo de todos. Algo parecido acurría en Alemania,...». Y sigue comentando el 
por Riley-Smith ${ }^{169}$, aunque ambos reconozcan las importantes aportaciones de Bull sobre otros aspectos de la cruzada.

Pero vayamos por partes. Dependiendo de lo que los autores entiendan por cruzada y cuales sean sus características definitorias, así será su concepto sobre la guerra peninsular contra los musulmanes y su influencia en el origen y desarrollo de las cruzadas. En general, los defensores de la heterogeneidad del modelo cruzado tenderán a ver una mayor, que menor, influencia de la guerra peninsular en el desarrollo y evolución de las cruzadas ${ }^{170}$, mientras que los defensores de la hipótesis de un sólo frente verán este papel mucho más reducido o inexistente. Ya hemos visto cómo desde Erdman, que negaba el carácter religioso de las guerras peninsulares en el siglo $\mathrm{X}$, los historiadores han tenido en cuenta el problema peninsular. Erdman citaba a Barbastro como protocruzada, pero una cruzada llevada a cabo por extranjeros y traída por éstos. A pesar de ello le concedía cierto protagonismo al escenario peninsular como campo de experimentación, destacando el caso de Tarragona; y decía, en fin, que no se podía hablar de la existencia de una guerra santa - propia a los peninsulares, en el siglo XIcuando éstos se aliaban entre sí sin importar la religión o convivian unos con otros ${ }^{171}$. Mayer también sacó el episodio de Tarragona pero desde otro punto de vista, enfocárıdolo desde la importancia de la fusión del elemento de peregrinación con el de guerra santa ${ }^{172}$. Riley-Smith también volvió sobre

caso de R. de Gilbart: "Sólo existe un cronista del siglo XI que muestre la guerra contra el Islam como un enfrentamiento puramento ideológico de blanco contra negro, como se hace en tiempo de las cruzadas (s. $x i l)$. Se trata de Raoul Gilbart $\left(n{ }^{\circ} 6\right)$ que tiene una clara conciencia de la cristiandad latina, que se opone netamene al Islam, a los países de la europa central y a la cristiandad bizantina, a los que guarda una violenta hostilidad. En un célebre pasaje celebra las victorias cristianas sobre el Islam en España, y presenta a sus muertos como beneficiarios de la vida eterna... Sin embargo este pasaje es excepcional si lo compararnos con el resto de escritores de su siglo, que raramente indican la existencia de una consciencia elevada de un enemigo exterior...» FRANCE, J., "Les origenes de la premiére croisade", 4 e Colloque Internationale de la society for the study of the crusades and the Latin East: Author de la premiére croisade, ed. M. Balard, pp. 43-56, Paris, 1996.

169 RILEY-SMITH, J., "Carl Erdman and the historiography of the crusades», La primera cruzada $900 . ., ;$ ídem, The first crusaders. Cambridge, 1997.

170 sobre todo ver HousLEY, N., "Jerusalem and the Development of the Crusade Idea, 1099 1128", 27-40, The Horns of Hattin. ed. Z. Kedar, Jerusalem, 1992.

171 Erdmann, A., A idea de Cruzada en Portugal. Coimbra, 1940, p. 5. Lo cierto es que en una cruzada se actua y mueve por muchos diferentes motivos, la complejidad del periodo histórico no tiene por qué hacernos adoptar posturas extremistas y simplistas.

172 «La guerra en españa no era una cruzada, aunque más tarde llegara a ser un sustitutivo de la cruzada (principalmente para los Franceses)... Los papas lo promovieron y las equipararon a la cruzda oriental; pero más que proto-cruzadas españolas eran sólo guerras santas, lo cual no es igual a cruzada; y de hecho no es hasta el pontificado de Urbano II cuando podemos ver la influencia de españa en el desarrollo del concepto de cruzada". MAYER, H.E., The Crusades. Oxford, 1972 (Trad. orig. Sttutgart, 1965). 
el mismo episodio destacando el fenómeno de guerra penitencial, para él fundamental aunque amplia un poco más la influencia peninsular. Mientras, historiadores clásicos españoles como Menéndez Pidal y, sobre todo, $\mathrm{B}$. Ruano, G. Gaztambide, o Riu Riu al afirmar las guerras de las reconquistas como guerras santas llaman a una influencia clara sobre origen de las cruzadas ya que directamente se habrían iniciado en el suelo peninsular. Por otra parte, desde otras posturas más legalistas, como Villey o especialmente Brundage hablan también del peso del escenario peninsular del siglo XI pero negando, tajantemente, el carácter de cruzada o protocruzada ${ }^{173}$, al carecer de un aspecto para el fundamental: el elemento de peregrinación ${ }^{174}$.

Para Kernaghan, desde su trabajo de síntesis, se puede considerar como antecedentes hispanos de la cruzada la petición del navarro Sancho III al papa de ayuda para evitar que el camino de Santiago y las tierras en general amenazadas volviesen a sufrir de los estragos, como las causadas por las recientes de Almanzor. O cuando en el 1014 el papa prometió tierras e indulgencias a los caballeros cristianos que luchasen contra el Islam. En cualquier caso, y confirmando la igualdad que el concilio de 1123 establecía entre la luchas en el frente Oriental como Peninsular, afir-

173 Brundage, J.A., Medieval canon law and the Crusades. Winsconsin, $1969, \mathrm{n} .{ }^{\circ} 91$. Aunque sea una larga cita merece la pena estudiar sus palabras como ejemplo de la postura legalista: «Así, por el tiempo que Gregorio VII (1073-1085) accedia al pontificado, sucediendo a Alejandro II, mucho de los principios básicos de la idea de cruzada ya habian sido establecidos en declaraciones papales e incorporados en las colecciones de cánones, la mayor parte de las cuales estaban en relación con las campañas en España, aunque las expediciones españolas diferían claramente de las propias cruzadas en muchas maneras diferentes... Elementos en común (entre cruzada y España) eran el hecho de que los participantes en las campañas españolas disfrutaran de bendiciones papales y que fueran recompensados con la remisión de los pecados, que la reconquista implicaba la guerra contra los sarracenos en defensa de la cristiandad y la recuperación de anteriormente territorios cristianos, y que sus heroes podrían incluso ser considerados como mártires; pero es una perversión de los términos el llamar a las cruzadas españolas como «cruzadas». Uno de las características más esenciales de las cruzadas es la fusión en ellas de las tradiciones de guerra santa y peregrinaje; de ésto no hay ningún signo en las campañas peninsulares del siglo xI. Si bien es cierto que eran guerras santas, tampoco es menos cierto que no fueron peregrinaciones. Los guerreros en las campañas españolas, aparentemente, no disfrutaron de las promeas de protección personal que se les otorgaba a los peregrinos en este tiempo o que se le otorgarian a los cruzados más adelante, ni disfrutaban de proteccion papal explícita de sus personas, propiedades y allegados que más tarde se otorgaría a los cruzados. No hay ninguna pista, hasta donde yo conozco, de nada parecido al voto de cruzada... también faltaban en las expediciones españolas la insignia de la cruz, los privilegios financieros de los que disfrutarian los cruzados, el "privilegium feri» y otros privilegios legales. Hasta donde podemos ver ni siquiera hubo una proclamacion formal papal de guerra, del tipo que sería común a las expediciones cruzadas. En definitiva, las cruzadas, hablando con propiedad, representaron un considerable ensanchamiento de perspectivas, elementos, ideas e instituciones que encontramos en la reconquista del siglo XI».

174 Posturas opuestas son las sostenidas por Mayer - ya visto-y, sobre todo, por Reynaud (REYNAUD, G. «La lutte chrétienne contre le pouvoir musulman en occident ou l'origin ibérique de la croisade d'orient", Sharq al-Andalus, 8 (1991): 243-247. 
ma que sólo se puede hablar de cruzadas verdaderas a: 1101, Zaragoza; 1114, Baleares; 1147 Almería; 1195, como parte de la III cruzada; 1212 las Navas de Tolosa ${ }^{175}$. A nuestro entender muestra una clara visión simplista del fenómeno...

En general, me atrevo a apoyar la idea de una clara influencia de las campañas de la Reconquista tanto en el origen como en la evolución del concepto y fenomenología cruzadas. Sin entrar en discusiones sobre la evolución del aspecto de la guerra santa ${ }^{176}$, o sobre el conjunto de fenómeno de «reconquista», o sobre si la guerra en el siglo XI era una guerra santa antes o después de Cluny ${ }^{177}$, hay otros aspectos prácticos que parecen evidentes: la península fue un escenario cruzado desde, al menos, el mismo momento de la promulgación de la primera cruzada en 1095. Así fue reconocido por los papas que se preocuparon por igualar los privilegios e indulgencias concedidas a los combatientes en Tierra Santa con los de la península y que procuraron retener a los hombres dentro de la misma para la lucha contra los sarracenos de al-Andalus. Es esa Península que se muestra como primer campo donde se pusieron en practica ciertas instituciones o desarrollos legales que luego se encontrarían en las cruzadas ${ }^{178}$

175 Kernaghan, P., Las cruzadas. Culturas en conflicto. Torrejón de Ardoz, 1994. Citamos esta obra no por su calidad científica sino por que es usado como instrumento de educación para alumnos preuniversitarios...

176 Ver las obras ya citadas de Erdmann, G. Gaztambide, más CANARD, M., «La guerre Sainte dans le monde Islamique et dans le monde Chrétien", Revue Africaine, 79 (1936): 605-623; The Holy War, ed. T. Patrick M. Ohio, 1976. CARDINI, F., "La Guerra Santa nella Cristianitá», "Militia Christi" e Crociata, conf., 387-399. Milan, 1992.

177 Últimamente, el profesor J. Flori está trabajando mucho en estas etapas iniciales de la cruzada y la Reconquista. Por ejemplo. FLoRY, J., «Reforme-reconquista-croisade. L'idée de reconquëte dans la corespondance pontificale d'Alexandre II á Urbain Il». Cahiers de Civilisation Médievale, 40 (1997): 317-345. Ídem, «Le vocabulaire de la «:econquête chrêtienne» dans las lettres de Gregoire VII". De Toledo a Huesca; sociedades medievales en transición a finales del siglo xl. Zaragoza, 1998, pp. 247-267. En este último trabajo, el autor dice que hay una continuidad, en cuanto al vocabulario utilizado por los Papas Gregorio y Urbano, entre Reconquista y la Primera Cruzada a Tierra Santa, y por lo tanto una es una prolongación de la otra. Sin embargo, el autor también dice que entre las dos hay una diferencia fundamental que se encuentra en la segunda, la cruzada, y no en la primera, la reconquista antes de 1096, como es el elemento de la peregrinación. También habla de la continuidad de la lucha peninsular antes de la toma de Toledo (tema de los cristianos oprimidos), y saca a la palestra un documento del papa Gregorio al conde de Borgoña (2/2/1074) sobre lo meritorio de la lucha en la península, al ser una guerra justa y sagrada, de reconquista.

178 Caso de la posible influencia del modelo de la confraternidad militar de Belchite en el orígen de las Órdenes Militares y ciertos elementos característicos de las cruzada como la obligación de servir durante un año para conseguir los privilegios cruzados íntegros. HousLEY, N. «Jerusalem and the Development of the Crusade Idea, 1099-1128", 27-40. The Horns of Hattin, ed. B.Z. Kedar, Jerusalem, 1992. (1987 conf.), que cita aprobatoriamente a Goñi y Lacarra. El texto de la indulgencia concedida a la cofradía de Belchite se puede encontrar en: RASSOW, P. "La cofradía de Belchite». Anuario de Historia del derecho español, 3 (1926): 224-226. 
y en la actuaron combatientes que luego participarian en la cruzada de $1096{ }^{179}$, etc. En cualquier caso la Península, desde el 1095, se convirtió en un frente cruzado indudable, reconocido por el papado y el mundo occidental. En general, tomando como uno de los elementos conformadores el del ideal de la recuperación de antiguas tierras cristianas sometidas al infiel, el conjunto de la reconquista se puede englobar dentro del fenómeno cruzado ${ }^{180}$, aunque luego haya que descender a saber qué campañas específicas eran real, «legalmente» cruzadas (campañas limitadas).

En resumen, a la hora de enfrentarse al problema sobre qué es cruzada y qué es reconquista, los historiadores hispanos han tenido que enfrentarse antes al asunto del carácter religioso o santo de la guerra en la península, desde cuándo - si es que estaba presente- y qué elementos influyeron en la consecución de una guerra de este tipo. La opción que se consideraba tradicionalista contemplaba a la reconquista animada desde un principio, o en su defecto desde el siglo $\mathrm{I} x$, de un fuerte carácter religioso siendo la lucha por la patria y la religión el tema fundamental. Esta visión fue la que imperó en España durante todo el régimen franquista y aún antes. Del otro lado tenemos la postura laica, que pretendía negar el carácter religioso de la guerra en la península o que ponía mucho más énfasis en los motivos políticos, económicos y sociales. Esta postura también existió a lo largo de todo el siglo, aunque durante el régimen franquista sus defensores apenas si se podían encontrar dentro de España. Con la década de los setenta y también junto a la influencia del marxismo histórico la postura «laica» gana adeptos, acompañada por trabajos que afirman la no continuidad de una idea de reconquista. Dicha tendencia, que no anuló la otra, fue la mayoritaria también en los ochenta ${ }^{181}$. Últimamente parece que la revalorización del elemento religioso como conformador y elemento característico de las cruzadas y la reconquista ha vuelto a ganar apoyos. No obstante, convendría no mostrarse radical en este aspecto: a una cruzada se podía acudir por motivos religiosos -en principop es algo primario ya que la recompensa es la remisiónb de la penitencia-, aunque muchas veces no fueran los únicos... no por ello debe dejar de considerarse cruzada.

179 Entre otros, DANIEL, N «Crusade propaganda», pp. 39-44. A History of the Crusades, VI. Hazard \& Setton ed, Winsconsin, 1989.

180 Aunque no entraremos aquí en este tema, parece que desde la península (luego reconocido por el papado) se llegó también a utilizar la justificación de la "vía africana" para remachar el carácter meritorio, cruzado, de la guerra en la península que contribuiría a la liberación de los Santos Lugares.

181 Ejemplo: Fernández-Armesto, F., Antes de Colón. Madrid, 1993 (orig. 1988), tesis colonialista. 
Sin embargo, y a pesar de algunas muestras recientes, aún se observa una cierta postura aislacionista de los historiadores hispanos, sean estos tradicionalistas o laicos, que les llevan a desestimar estudios foráneos. Bien es cierto que una mayoría de historiadores extranjeros no tienen presente la realidad peninsular o demuestran un claro desconocimiento al respecto, principalmente por que no se molestan en leer bibliografía en castellano o portugués ${ }^{182}-0$, en el mejor de los casos se han quedado anquilosados en las posturas de Menéndez Pidal, Albornoz, Castro y compañía-. No obstante otros historiadores sí que han mostrado un profundo conocimiento de la realidad peninsular como Burns, Lomax, Fletcher, Housley, etc. que, desde distintos enfoques, han contribuido a enriquecer la historiografía sobre las cruzadas y la península ibérica.

182 Por ejemplo, Maier, aunque confiesa su desconocimiento del caso peninsular se atreve a realizar unas conclusiones al respecto que muestran la falta de familiaridad con los acontecimientos peninsulares y con la diplomática peninsular-vaticana-africana. (MAIEP, Ch. T., Preaching the Crusades: Mendicant Friars and the Cross in the thirteenth century, Cambridge, 1994.) 